\title{
Sources of Contrarian Profits in the Japanese Stock Market ${ }^{+}$
} Pin-Huang Chou ${ }^{\text {a }}$, K.C. John Wei ${ }^{\text {b,* }}$, Huimin Chung ${ }^{\text {c }}$

${ }^{a}$ Department of Finance, National Central University, Chung Li, Taiwan 320. Tel: (886)-3422-7151 ext. 66270; Fax: (886)-3425-2961; Email: choup@cc.ncu.edu.tw

${ }^{\mathrm{b}}$ Department of Finance, Hong Kong University of Science and Technology, Clear Water Bay, Kowloon, Hong Kong. Tel: (852)-2358-7676; Fax: (852)-2358-1749; Email: johnwei@ust.hk

${ }^{c}$ Graduate Institute of Finance, National Chiao-Tung University, Hsinchu, Taiwan 300. Tel: (886)-35712121 ext. 57075; Fax: (886)-3573-3260; Email: chunghui@mail.nctu.edu.tw

\begin{abstract}
This paper investigates the profitability of contrarian strategies on the Tokyo Stock Exchange (TSE) across various ranking and holding horizons ranging from one month to three years. In sharp contrast to the evidence from the U.S. and European markets, our data show that contrarian strategies are profitable in Japan across all horizons, especially with a very short horizon of one month or a very long horizon of two years or longer. The results are very robust to skipping one month between the holding and ranking periods, excluding firms with extreme past returns, and partitioning the whole sample into bull and bear subperiods. In addition, we find that contrarian strategies perform much better when the aggregate market also performs better in either the ranking or the holding period. Finally, contrarian profits are mostly attributed to the lead-lag effect. Further analysis indicates that contrarian profits are not attributed to the pricing errors of the Fama-French three-factor model. Instead, contrarian profits are mainly due to cross-autocorrelations among firm-specific error components of the Fama-French three-factor model.
\end{abstract}

JEL Classification: C13; C53; G14

Key Words: Contrarian strategy; Momentum strategy; Lead-lag effect; Autocorrelation; Cross-autocorrelation; Investment horizon

\footnotetext{
${ }^{+}$Comments and suggestions from Shinn-Ju Lin and seminar participants at the National Central University, National Tsinghua University, the Eighth SFM Conference, Kaoshiung, Taiwan, and the 2000 Asian Pacific Finance Association Meetings, Shanghai, PRC, are gratefully acknowledged. The authors also thank Dr. Virginia Unkefer for editorial assistance. Pin-Huang Chou thanks the National Science Council of Taiwan (Grant no: NSC 89-2416-H-008-008) for financial support, and John Wei acknowledges financial support from the Research Grants Council of the Hong Kong Special Administrative Region, China (HKUST6233/97H).

${ }^{*}$ Corresponding author: K.C. John Wei, Department of Finance, Hong Kong University of Science and Technology, Clear Water Bay, Kowloon, Hong Kong. Tel: (852)-2358-7676, Fax: (852)-2358-1749, Email: johnwei@ust.hk.
} 


\section{Introduction}

Past return-based investment strategies, such as contrarian and momentum strategies, have been employed by practitioners for decades and have been investigated extensively by academics in recent years. The profitability of these strategies has been considered to be attributed, at least to some extent, to the predictability of security returns. Even though the profitability of these passive investment strategies seems to refute the efficient market hypothesis, much research effort has been devoted to explaining why such predictability exists and if it can be consistent with the efficient market hypothesis.

De Bondt and Thaler $(1985,1987)$ suggest that extremely well or poorly performing securities will rebound to correct the pricing bias caused by market overreaction. That is, winner and loser stocks tend to be negatively autocorrelated. As a result, a contrarian portfolio that is formed by buying past loser stocks and at the same time shorting an equal amount of past winner stocks will be profitable, because this contrarian portfolio is also negatively autocorrelated. De Bondt and Thaler find that, in the U.S., contrarian strategies based on the past three- to five-year returns are profitable for a holding period of three to five years.

In contrast, Jegadeesh (1990), Jegadeesh and Titman (1993, 2001), Chan et al. (1996), and many others find that, in the U.S. and Europe, a momentum strategy (or a "counter-contrarian" strategy) that is formed by buying past winners and selling past losers is profitable for both ranking and holding periods ranging from three months to one year. ${ }^{1}$ Instead of overreaction, the markets seem to underreact to information in the medium term.

Lo and MacKinlay (1990) show that negative serial correlation alone does not assure that there will be contrarian profits, however. They show that contrarian profits may exist, if there are positive cross-autocorrelations (i.e., lead-lag relations) among the component stocks. Using weekly return data from the U.S. market, they find that overreaction (i.e., negative autocorrelation

\footnotetext{
${ }^{1}$ Other evidence on momentum profits in the U.S. market is documented in Grundy and Martin (2001), Hong and Stein (1999), Lee and Swaminathan (2000), and Moskowitz and Grinblatt (1999), among others. Similar evidence is also found in the U.K. stock market (Liu et al. (1999)). Other international evidence on the profitability of momentum strategies is reported by Griffin et al. (2003), Grinblatt and Keloharju (2000) and Rouwenhorst (1998, 1999), among others.
} 
in stock returns) accounts for less than 50 percent of the contrarian profit. $^{2}$ Based on an alternative decomposition that relates time-series predictability to a factor model, Jegadeesh and Titman (1995) conclude that short-term contrarian profits are mostly attributed to investors' overreactions to firm-specific information, rather than to the lead-lag relation.

Conrad and Kaul (1998) provide a comprehensive investigation of contrarian or momentum strategies over various horizons and confirm the early evidence that a contrarian strategy works over short and long horizons, while a momentum strategy performs well over medium horizons, ranging between one month and one year. They further point out that it is the cross-sectional variation in expected returns of individual securities that plays the major role, rather than the time-series pattern of the individual securities. ${ }^{3}$ In sum, empirical results from the U.S. markets appear to support the notion that stock returns are negatively autocorrelated in the very short term, then become positively serially correlated in the medium term, and finally return back to be negatively serially correlated in the long term, as documented, for example, by Poterba and Summers (1988) and Fama and French (1988).

Our paper contributes to the literature in three aspects. First, we consider various issues regarding contrarian strategies on Japanese stocks in the 1979-1997 period. As argued in Jegadeesh and Titman (2001), it is important to test the robustness of momentum/contrarian profits on different samples as the patterns of trading profits documented in the U.S. market may not be universal. Jegadeesh and Titman (2001) test the robustness of momentum profits using a U.S. sample after 1989 (i.e., 1990-1997). ${ }^{4}$ Although Japan is the world's second largest in terms of market capitalization, whether contrarian/momentum strategies are profitable in Japan has not been well studied. In addition, Japan differs from the U.S. in several aspects such as cultural

\footnotetext{
${ }^{2}$ Other evidence on contrarian profits in the U.S. market is documented by Conrad et al. (1997), Dechow and Sloan (1997), and Lehman (1990), among others. Bacmann and Dubois (1998) report contrarian profits in the French market. A number of papers are devoted to explaining contrarian profits such as those by Ball et al. (1995), Chan (1988), Chopra et al. (1992), Jones (1993), Lakonishok et al. (1994), and Peter (1994), among others.

${ }^{3}$ See Jegadeesh and Titman (2002) for a different view.

${ }^{4}$ Kato (1990) examines a few “anomalies” in the Tokyo Stock Exchange using a smaller sample over the 1973-1987 period. He finds significant reversals for both loser and winner stocks only prior to 1980, but not afterwards. He suggests that this may be related to increasing institutional trading in the market after 1980. Our study examines various issues regarding contrarian profitability using a larger sample with updated data.
} 
backgrounds and institutional structures. Social psychology literature has documented that cultural backgrounds and institutional structures may influence investor behavior such as overconfidence, self-attribution bias, and conservatism, which may, in turn, affect the profitability of momentum/contrarian strategies. Recent research in behavioral finance tries to explore non-risk based explanations for the contrarian/momentum profitability. Thus, it makes sense to compare the contrarian/momentum profitability in countries with significant cultural and institutional differences.

Second, as discussed above, the length of the ranking and holding periods may play crucial roles in the performance of a contrarian/momentum strategy. Given a particular return-generating process or a return time-series structure, a stock may be identified as both a loser and a winner, depending on the length of the ranking period chosen. Likewise, a portfolio's performance after formation may also depend on the length of the holding period, as evidenced by Jegadeesh and Titman (2001). Although Conrad and Kaul (1998) investigate contrarian/momentum performance over various ranking and holding horizons, they consider only "symmetric” cases where the length of the ranking and holding periods is identical. Hence, it would be of interest to examine the shortand long-term performance of a contrarian/momentum strategy based on "asymmetric" lengths of ranking and holding periods.

The existing decomposition method for contrarian returns in Lo and MacKinlay (1990), Jegadeesh and Titman (1995), and Conrad and Kaul (1998) assumes symmetric lengths of ranking and holding periods. This "symmetric" assumption is restrictive in that we cannot examine the sources of profitability across a full spectrum of various lengths of the holding period for a given length of ranking period. For example, Jegadeesh and Titman (2001) find that a momentum strategy based on the past six-month returns is profitable only up to 12 months. After 12 months, the momentum strategy starts to lose money. To understand the full spectrum of the sources of contrarian/momentum profits across various holding periods for a given ranking period such as the time-series pattern of the profitability of momentum strategies documented by Jegadeesh and Titman (2001), we extend the decomposition of contrarian profits to asymmetric lengths of 
ranking and holding periods.

Finally, although Jegadeesh and Titman (1995) decompose the time-series predictability of a contrarian/momentum portfolio into a factor component and a firm-specific component, their decomposition is not designed to explain the extent to which the proportion of the trading profit is normal compensation for bearing risk. We extend their model to examine whether contrarian profits can be explained by the Fama-French $(1993,1996)$ three-factor model.

In sharp contrast to the evidence from the U. S. and European markets, we find that contrarian strategies are profitable in Japan on all horizons, especially over a very short horizon of one month or a very long horizon of two years or longer. In addition, when we skip one month between the ranking period and the holding period or exclude firms with extreme past returns, although contrarian profits reduce substantially with a horizon of one year or shorter, the effect is very marginal for a horizon of two years or longer. Surprisingly, contrarian profits during the bull market of 1975-1989 is about the same as during the bear market of 1990-1997. Finally, we find that contrarian profits are mostly attributed to the lead-lag effect, rather than to market overreaction as evidenced in the U.S. Further analysis shows that contrarian profits are not attributed to the pricing errors of the Fama-French three-factor model. Rather, they are due to cross-autocorrelations in firm-specific error components. These results suggest that contrarian profits in the Japanese stock market cannot be explained by behavioral models.

The distinctive contrarian/momentum performance in the Japanese stock market merits further investigation. Hofstede (1991) finds that people in Western countries tend to score higher in the tests of "individualism" than do people in Asia. While it is not obvious how a tendency to think and act more or less independently relates to momentum or contrarian effects, it is quite plausible that individualism is related to "conservatism," "overconfidence," and "self-attribution bias," which have been suggested by Barberis et al. (1998) and Daniel et al. (1998) as determinants of momentum profits. ${ }^{5}$ In addition, Daniel et al. (1998) also discuss this possibility and cite a

\footnotetext{
${ }^{5}$ Chui et al. (2006) discuss the relationship between individualism and overconfidence, self-attribution bias, and conservatism. In addition, they find that the momentum profitability in a country is positively related to its score on the
} 
paper by Kitayama et al. (1995) that suggests that the Japanese show no evidence for what they call “self-enhancing attribution.” This may explain why we observe no momentum effects in Japan.

The rest of the paper proceeds as follows. Section 2 describes the data. Section 3 reports the profits of contrarian strategies in the Japanese market based on the design of Jegadeesh and Titman (1993). Section 4 provides robustness checks by skipping one month between the ranking and holding periods, by excluding firms with extreme past returns, and by partitioning the whole sample period into the bull-market subperiod of 1975-1989 and the bear-market subperiod of 1990-1997. Section 5 examines contrarian profits by partitioning the whole sample into two sub-samples based on the aggregate market performance during either the ranking or the holding period. Section 6 studies contrarian profits in event time. Section 7 investigates the sources of contrarian profits using an asymmetric decomposition structure and examines whether contrarian profits can be explained by the Fama-French three-factor model. Finally, Section 8 concludes.

\section{The data}

Our study examines monthly data on common stocks listed on both sections of the Tokyo Stock Exchange (TSE) from January 1975 to December 1997. As noted in Chan et al. (1991), stocks listed on the TSE account for more than 85 percent of the total market capitalization of Japanese equities. Our data are from several sources. Monthly returns including dividends and market capitalization are from databases compiled by the PACAP Research Center, the University of Rhode Island (1975-1997). The monthly value-weighted market returns of both sections of the TSE are also from this data source. There are no risk-free rates in Japan that are comparable to the U.S. Treasury bill rates. As a result, we follow Chan et al. (1991) by using a combined series of the call money rate (from January 1975 to November 1977) and the 30-day Gensaki (repo) rate (from December 1977 to December 1997) as the risk-free interest rate. This interest rate series is taken from the PACAP databases (1975-1997). The data on book values are taken from both the PACAP 
databases and Nihon Keizai Shimbun, Inc., Tokyo.

To construct the Fama-French three factors, we follow the procedures proposed by Fama and French (1993) in general and by Daniel et al. (2001) in particular. Specifically, we form factor portfolios sorted on market size (SZ) and book-to-market equity (BM). Daniel et al. (2001) include a detailed description of the construction of the Fama-French three factors in the Japanese market. We wish to ensure that the accounting data that we use in forming these portfolios are publicly available at the time of portfolio formation. Most firms listed on the TSE have March as the end of their fiscal year and the accounting information becomes publicly available before September. Therefore, we form portfolios on the first trading day of October, and hold them for exactly one year. For portfolios formed in October of year $t$, we use the book equity $(B E)$ of a firm at the fiscal year-end that falls between April of year $t-1$ and March of year $t$. BM is set to equal the ratio of $B E$ to the market equity at the end of March of year $t$ and $S Z$ is set to equal the market equity at the end of September of year $t$. The portfolios are rebalanced every year. To compute the intercepts and the time-series of residual terms in the Fama-French three-factor model, we use all available data, which means that we assume that the return-generating process is stationary.

Our sample contains 1,854 firms, each of which has observations for up to 275 monthly returns. To avoid survivor biases, we do not require a security to survive in the entire holding period. In particular, if a security is included in the $p$-period contrarian portfolio based on its past $p$-period performance and it survives for less than $q$ periods in the future (because of trading suspension or being delisted), we calculate its holding period from time $t$ up to its last trading month. The formation of zero-cost contrarian portfolios closely follows Jegadeesh and Titman (1993, 2001) and Lo and MacKinlay (1990).

\section{Profits of contrarian trading strategies}

This section examines the profits of contrarian strategies across various lengths of ranking and holding horizons. Let a $(p, q)$-strategy denote a contrarian strategy held for $q$ months based on the returns over the past $p$ months, where $p$ and $q$ are set as $1,3,6,9,12,24$, and 36 . Thus, in 
combination, we have 49 strategies.

Following the design of Jegadeesh and Titman (1993), we use overlapping data to increase the power of our tests. Specifically, at the beginning of each month, $t$, all stocks are ranked in ascending order on the basis of their returns in the past $p$ months. Based on these rankings, ten equally weighted decile portfolios are formed; the first decile portfolio is the "loser" portfolio, while the last decile portfolio is the "winner" portfolio. A $(p, q)$-contrarian portfolio is formed by buying the loser portfolio and selling the winner portfolio. The contrarian portfolio is held for $q$ months. Our strategies resemble those of Jegadeesh and Titman (1993) except that the holding positions are opposite.

Table 1 and Figure 1 present the average monthly returns of the loser (buy) and the winner (sell) portfolios as well as the zero-cost contrarian (loser minus winner) portfolio for the 49 strategies described above. Several interesting observations emerge from Table 1. First, we find that unlike the U.S. evidence that contrarian strategies work only on long horizons, the results in Table 1 indicate that contrarian strategies are significantly profitable on the TSE across all ranking and holding horizons ranging from one month to three years (see also Figure 1). The returns on the loser and the winner portfolios are positive across almost all ranking and holding horizons with two minor exceptions; the average returns on the $(1,1)$ - and the $(3,1)$-winner portfolios are negative, but are statistically insignificant.

[Put Table 1 and Figure 1 about here]

The results in Table 1 suggest that the major source of contrarian profits comes from return reversals in loser (buy) portfolios. In particular, the reversals in loser portfolios persist for all horizons and result in an average monthly return of greater than one percent for almost all cases. While winner portfolios also experience reversals following the formation period, the reversals occur only in the first month with the ranking period of three months or less. The results indicate that the average monthly returns on winner (sell) portfolios increase as the holding horizon increases, regardless of the length of ranking period. As returns on winner portfolios are positive in almost all cases, one would have generated greater profits by holding long positions on loser 
portfolios alone. The results suggest that contrarian profits are not affected by the restrictions on short selling.

Contrarian profit is obviously related to the ranking horizon and the holding horizon. When holding the ranking horizon fixed at one month, the contrarian profit decreases monotonically from $2.400 \%$ to $0.190 \%$ as the holding horizon increases. When holding other ranking horizons fixed, the contrarian profit decreases first and then increases as the holding period increases. This U-shaped relation between the contrarian profit and the holding horizon is initially skewed to the left when the ranking horizon is short, but the left skewness of the U-shaped relation reduces gradually and becomes almost symmetric when the holding horizon is two or three years.

When holding the holding period fixed at one month, the contrarian profit decreases initially as the ranking horizon increases, but it tails off at around $1.10 \%$ after one year. On the other hand, when holding the holding horizon fixed at one year and longer, the contrarian profit increases almost monotonically with the ranking horizon. We also observe that with a longer ranking horizon of two or three years, the average monthly contrarian profit appears not to be affected by the length of holding horizon too much. More specifically, the average monthly contrarian profit ranges from $0.646 \%$ to $1.088 \%$ for the ranking horizon of two years, and $0.807 \%$ to $1.126 \%$ for the ranking horizon of three years.

\section{Robustness checks}

In this section, we perform several checks on the robustness of the contrarian profitability documented in the last section. We first consider the case when contrarian portfolios are formed one month following the formation period. The one-month gap between the formation period and the holding period is intended to reduce potential biases induced by nonsynchronous trading and bid-ask bounces. We then implement strategies on a reduced set of stocks by excluding firms that are ranked in the top and the bottom $2.5 \%$ in the ranking period. Finally, we perform subperiod analyses by splitting the whole sample period into two subperiods, using 1990 as the break point at which the Japanese markets became bearish. 


\subsection{Skipping one month}

The contrarian strategies as described in the last section are carried out immediately after the portfolio ranking periods, and, therefore, may suffer from the potential impact of the bid-ask bounce, the price pressure, and the lagged reaction documented by Jegadeesh (1990) and Lehman (1990). To reduce these effects, we follow Jegadeesh and Titman (1993) by implementing the contrarian strategies that skip one month between the ranking period and the holding period. To save space, we only report empirical results that are based on contrarian strategies that have symmetric or equal ranking and holding horizons. The results are reported in Table 2.

[Put Table 2 about here]

Panel A of Table 2 indicates that return reversals are, in general, much less prominent for both buy and sell portfolios when there is a one-month gap between the ranking and holding periods than when there is not. The reduction in return reversals results in reduced contrarian profits for all horizons and particularly for shorter horizons. This result is related to microstructural factors. For instance, the profit of the $(1,1)$-contrarian strategy drops significantly from $2.400 \%$ per month without a one-month gap to only $0.616 \%$ with a one-month gap, although it is still statistically significant. A closer inspection suggests that the average monthly return reduces from $1.977 \%$ to $0.993 \%$ for the loser (or buy) portfolio, but increases from $-0.423 \%$ to $0.378 \%$ for the winner (sell) portfolio. However, once the ranking/holding horizon increases, the effect of skipping one month on the contrarian profit decreases substantially, especially for the horizon of two or three years. For example, the $(24,24)$-strategy generates a monthly contrarian profit of $0.738 \%$ with skipping one month versus $0.774 \%$ without skipping one month, while the $(36,36)$-strategy generates a monthly contrarian profit of $0.859 \%$ with skipping one month versus $0.873 \%$ without skipping one month.

Overall, the results with a one-month gap between the ranking and holding periods indicate that contrarian strategies are still statistically profitable for all ranking/holding horizons except for the medium horizons of three to nine months. A U-shaped relation between average monthly 
returns and ranking/holding horizons is still present in contrarian portfolios. We also find that most of the contrarian profit comes from long-run reversals in loser (buy) portfolios. For example, while the $(36,36)$-strategy generates an average monthly return of $1.344 \%$ for the loser (buy) portfolio, it generates a monthly return of only $0.485 \%$ for the winner (sell) portfolio.

A comparison of the results in Tables 1 and 2 shows that the obvious reasons for why contrarian strategies work on the short horizon in Japan mainly come from bid-ask bounces and short-term reversals. It has been documented that stocks with high book-to-market equity are typically long-term losers. As a result, the reasons for why contrarian strategies work on the long horizon in Japan might be due to the value effect. In fact, Daniel et al. (2001) find that the book-to-market effect (or the value effect) is substantially higher in Japan than in the U.S. In particular, during the 1975-1997 period, Daniel et al. (2001) report that the mean return for the $H M L$ (high minus low book-to-market) portfolio is 0.68 percent per month in Japan, while it is only 0.41 percent per month in the U.S. In Section 7.2, we formally test whether contrarian profits can be explained by the Fama-French three-factor model and find that contrarian profits are not attributed to the pricing errors in the Fama-French three-factor model, confirming that the reason for why contrarian strategies are profitable in Japan is the value effect.

\subsection{Trimming observations of extreme returns}

As a robustness check to see how contrarian profits are sensitive to extreme observations, we examine contrarian profits by trimming 2.5 percent each of the top and bottom extreme observations of returns in the ranking period. ${ }^{6}$ The results are summarized in Panel B of Table 2. The empirical results show that contrarian strategies remain statistically profitable for short (one month and three months) and long (one year and longer) ranking/holding horizons, and that the U-shaped relation between the average monthly contrarian profit and the ranking/holding horizon is still maintained. However, contrarian profits also are significantly decreased compared with

\footnotetext{
${ }^{6}$ Knez and Ready (1997) document that the risk premium on size documented by Fama and French (1992) completely disappears when one percent of extreme observations is trimmed.
} 
those reported in Table 1. For a ranking/holding horizon of nine months or longer, the reduction in contrarian profit is even greater after trimming extreme observations than with skipping one month. For example, the $(36,36)$-strategy generates a monthly contrarian profit of $0.591 \%$ after trimming extreme observations compared with $0.859 \%$ with skipping one month.

\subsection{Subperiod analysis}

Our empirical tests examine data from 1975 to 1997. This was quite an interesting period in Japan. There were major financial deregulations and a stock market boom period followed by a crash. Kang and Stulz (2000) find that the stocks of bank-dependent firms perform significantly differently before and after 1990, the time that corresponds with the deregulations and with the first stage of the stock market decline. As a result, we also perform subperiod analysis to examine whether the profitability of contrarian strategies depends on a bull or a bear market. The results are reported in Panels C and D of Table 2.

Panel C of Table 2 shows that the average monthly returns on loser (buy), winner (sell), and contrarian portfolios are positive for all cases during the 1975-1989 bull-market subperiod. In particular, loser (buy) portfolios yield an average monthly return ranging from $1.675 \%$ to $2.632 \%$. Interestingly, the 1975-1989 bull-market subperiod generates monthly contrarian profits that are almost comparable with those in the whole sample period. But for the ranking/holding horizon of one month, the contrarian strategy actually generates a smaller profit in the bull market than in the whole sample period. Nevertheless, the U-shaped relation between the contrarian profit and the ranking/holding horizon still holds. Panel D of Table 2 reports the results for the 1990-1997 bear-market subperiod. The average monthly returns are negative for almost all loser and winner portfolios, except for the loser portfolios with the ranking/holding horizon of one month, two years and three years and the winner portfolio with the ranking/holding horizon of three years. Surprisingly, contrarian strategies perform even better in the 1990-1997 bear-market subperiod than in the 1975-1989 bull-market subperiod, except for the ranking/holding period of three months. The U-shaped relation between the contrarian profit and the ranking/holding horizon still 
holds. However, contrarian profits mainly come from winner (sell) portfolios, suggesting that if there is a restriction on short selling, contrarian profits will disappear except when the ranking and holding periods are two years or longer.

Overall, the empirical results show that contrarian profitability is robust to skipping one month, to excluding extreme observations, and to either a bull or a bear market. The empirical results also indicate that while contrarian profits are mostly attributed to persistent mean reversals in loser portfolios for the whole period and the pre-1990 subperiod, mean reversals in winner portfolios are the major source of contrarian profits in the 1990s except for a horizon of two years or longer. In addition, the U-shaped relation between the contrarian profit and the ranking/holding horizon holds for all cases.

A practical question is whether these contrarian strategies are still profitable after transactions costs. We assume that there is a one-way transaction cost of $0.5 \%$, which is probably reasonable for institutional investors during our sample period and is at the high end of transactions costs in recent years. This assumption translates to a total transactions cost of no more than $2.0 \%$ to use a contrarian strategy. The results from Tables 1 and 2 indicate that after taking into account transactions costs, contrarian strategies are not particularly profitable when the ranking and holding horizons are less than nine months, especially when there is a one-month gap between the ranking and holding periods. However, contrarian strategies are still very profitable when both ranking and holding horizons are two or three years. Since the returns on loser and winner portfolios are all positive in the 1975-1989 bull-market period, the profitability of contrarian strategies is not affected by the restriction on short selling during this period. However, since the returns on winner (sell) portfolios are all negative for the ranking and holding periods of two years or less in the 1990-1997 bear-market period, contrarian strategies are not very profitable during this period when there is a restriction on short selling, except when the ranking and holding periods are two or three years.

\section{Contrarian profits under different market conditions}


Our subperiod analysis presented in the previous section presumes that contrarian strategies may differ in performance in bull and bear markets, using 1990 as a rough cut-off point to split the whole sample into bull and bear markets. In this section, we further consider two different ways to classify the up and down market conditions. We first consider the case of symmetric strategies (i.e., $p=q$ ). That is, returns on portfolios are grouped into up or down market segments based on the magnitude of the market return over the holding period. Specifically, let $M k t(t, t+q)$ denote the cumulative return on the value-weighted index of all stocks listed on the TSE from month $t$ to month $t+q$. The returns on the winner, the loser, and the contrarian portfolios are classified into the up (down) market segment if the market index return is positive (negative) during the holding period, i.e., $\operatorname{Mkt}(t, t+q)>0(M k t(t, t+q)<0)$.

The average monthly returns for the three portfolios over various ranking and holding horizons $(p=q)$ for the up and the down markets are reported in Panels A and B of Table 3, respectively. Panel A of Table 3 indicates that contrarian strategies perform much better in the up market than in the whole sample period across all ranking and holding horizons. In the down market, contrarian strategies do not perform well. For the short horizons of three months to one year, contrarian profits are either insignificant or even negative. However, for a very short horizon of one month or very long horizons of two and three years, contrarian profits are still economically and statistically significant, even though they are substantially reduced.

[Put Table 3 about here]

In addition to identifying up and down markets based on market returns over the holding period, we also classify market conditions based on market returns over the ranking period, which is more realistic from an investor's point of view. The market is classified as up (down) if the market index return is positive (negative) in the ranking period of one year, i.e., $M k t(t-12, t)>0$ $(M k t(t-12, t)<0)$. Panels C and D report the results for the $(12, q)$-strategies with positive and negative ranking-period market returns, respectively. The results indicate that, for the holding horizon of one year, the previous market condition has a significant impact on the profitability of contrarian strategies. When the previous one-year market is up, contrarian strategies are very 
profitable for all holding horizons ranging from $0.490 \% /$ month for three years to $1.748 \% /$ month for one month. In contrast, when the previous one-year market is down, contrarian profits are negative for the holding horizons of nine months or less. Contrarian strategies are still significantly profitable for the holding horizons of two years or longer.

Panels E and F present results for the (36,q)-strategies. That is, the ranking period is three years. The patterns are similar to those observed from Panels C and D. More specifically, when the previous three-year market is up, contrarian strategies are very profitable for all holding periods with the contrarian profit ranging from $0.948 \%$ to $1.973 \%$ per month. However, profitability decreases monotonically when the holding horizon increases. On the other hand, when the previous three-year market is down, contrarian strategies lose money for the holding horizons of nine months or less. Contrarian strategies are still very profitable with a profit of $0.533 \%$ to 0.637\% per month when the holding horizons are two years or longer. Interestingly, by comparing the numbers in Panels $\mathrm{C}$ and $\mathrm{E}$ with the numbers in Panels $\mathrm{D}$ and $\mathrm{F}$, we can see that in either the up or down markets, rankings based on the past three-year returns yield better performance than do rankings based on the past one-year returns.

\section{Contrarian profits in event time}

In this section, we examine the returns of the contrarian portfolio in event time to see how the strategy works over time. We consider two typical strategies, one based on the past six-month returns, and the other based on the past two-year returns. The ranking period of six months has been used extensively in studying momentum strategies, while the ranking period of two years or longer is typically used to examine contrarian profitability. We track the average portfolio returns in each of the 36 months following the portfolio formation date.

Panel A of Table 4 and Figure 2 present the average monthly and the cumulative returns of the contrarian strategy in each of the 36 months following the portfolio formation date based on the six-month ranking period. The average return is significant in the first month, becomes negative from the third month through the ninth month, and reverses back to being positive from the tenth 
month on to the end of the third year. Figure 2 indicates that contrarian profits within an annual holding period are mostly induced by the profit in the first month, echoing the result in Panel A of Table 2 in which contrarian profits become insignificant when the strategies are implemented with a one-month lag. As suggested by Jegadeesh and Titman (1993), the returns on contrarian portfolios would have become negative if the strategies systematically chose stocks that had higher than average unconditional returns. However, since the average return is positive from the tenth month to the end of the third year, the pattern is by no means explicable by any asset-pricing model.

\section{[Put Table 4 and Figures 2]}

Panel B of Table 4 and Figure 3 present the average monthly and the cumulative returns of contrarian strategies based on the past two-year returns. The results indicate that the average return is positive and mostly statistically significant for each of the next 36 months. Thus, our event study evidence suggests that time-series dependency in component stocks appears to be the major reason for contrarian profits, especially over the long run. In the following, we further identify if the time-series dependency is attributed to overreaction or the lead-lag relation.

[Put Figure 3 about here]

\section{Sources of contrarian profits}

Various momentum or contrarian strategies have been investigated in the literature. In addition to their differences in choosing the lengths of the ranking period and the holding period, these strategies differ in the criteria of component stock selection and the portfolio construction method. Before we go into detail in examining the sources of contrarian profits, we introduce some notation. Specifically, let $R_{i}(t, t+k)$ denote the return on stock $i$ holding from time $t$ to time $t+k$, and let $R_{i t}=R_{i}(t-1, t)$ denote the one-period return holding from time $t-1$ to $t$. Notice that one period can be one week, one month, etc., depending on the investigator's interest.

Let $R(t, t+k)$ be an $N \times 1$ column vector of $k$-period returns on $N$ stocks, and let $R_{t}=R(t-1, t)$ refer to the vector of one-period returns from time $t-1$ to time $t$. Denote the mean 
of $R_{t}$ as $\mu$, and its $k$-th order autocovariance matrix as $\Gamma_{k}=E\left[\left(R_{t-k}-\mu\right)\left(R_{t}-\mu\right)^{\prime}\right], k \geq 0$. An equally weighted "market portfolio" of all stocks can be written as:

$$
R_{m, t}=R_{m}(t-1, t)=\frac{1}{N} \sum_{i=1}^{N} R_{i}(t-1, t)=\frac{1}{N} \mathbf{1}^{\prime} R(t-1, t)
$$

where $\mathbf{1}$ denotes a column vector of ones. Hence, the one-period market portfolio return has an

expected value of $\mu_{m}=\frac{1}{N} \mathbf{1}^{\prime} \mu$ and a $k$-th order autocovariance of $\frac{1}{N^{2}} \mathbf{1}^{\prime} \Gamma_{k} \mathbf{1}$.

\subsection{An extension of Lo and MacKinlay}

In this section, we extend the Lo and MacKinlay (1990) framework to allow for asymmetric lengths of ranking and holding periods. A contrarian strategy that is based on the past $p$-period returns and that holds a zero-cost position for $q$ periods is referred to as a $(p, q)$-contrarian strategy. Define the weight on stock $i$ based on a past $p$-period cumulative return as $w_{i t}(p)=-\frac{1}{N_{t}}\left[R_{i}(t-p, t)-R_{m}(t-p, t)\right]$, where $N_{t}$ denotes the number of stocks at time $t$ and $R_{m}(t-p, t)$ is the p-period cumulative return on a market index as defined as follows:

$$
R_{m}(t-p, t)=\frac{1}{N_{t}} \sum_{i=1}^{N_{t}} R_{i}(t-p, t)=\frac{1}{N_{t}} \mathbf{1}^{\prime} R(t-p, t) .
$$

Note that this market index represents a buy-and-hold portfolio that assigns an equal weight to each component stock in the initial investment at time $t-p$ and holds for $p$ periods. This differs from the equally weighted index defined in equation (1), which is essentially a rebalanced equally weighted portfolio.

To simplify the notation, we sometimes drop the subscript $t$ in $N_{t}$. Let $w_{t}(p)=\left(w_{1 t}(p), \ldots, w_{N t}(p)\right)^{\prime}$, which can be represented as:

$$
\left.w_{t}(p)=-\frac{1}{N} R(t-p, t)+\frac{1}{N^{2}} \mathbf{1 1}^{\prime} R(t-p, t)\right)=\left(-\frac{1}{N} I_{N}+\frac{1}{N^{2}} \mathbf{1 1}^{\prime}\right) R(t-p, t) .
$$

The profit of the contrarian portfolio formed based on the returns from $t-p$ to $t$ and on holding from $t$ to $t+q$ is as follows: 


$$
\begin{aligned}
\pi_{t}(p, q) & =w_{t}(p)^{\prime} R(t, t+q) \\
& =-\frac{1}{N} R(t-p, t)^{\prime} R(t, t+q)+\frac{1}{N^{2}} \mathbf{1}^{\prime} R(t-p, t) R(t, t+q)^{\prime} \mathbf{1} .
\end{aligned}
$$

Let the $q$-period holding return, $R(t, t+q)$, be approximated by the simple sum of $\sum_{l=1}^{q} R_{t+l}$.

Then, equation (4) becomes:

$$
\pi_{t}(p, q) \approx-\frac{1}{N} \sum_{i=1}^{N}\left[\left(\sum_{l=0}^{p-1} R_{i, t-l}\right)\left(\sum_{l=1}^{q} R_{i, t+l}\right)\right]+\frac{1}{N^{2}} \sum_{i} \sum_{j}\left[\left(\sum_{l=0}^{p-1} R_{i, t-l}\right)\left(\sum_{l=1}^{q} R_{j, t+l}\right)\right] .
$$

Thus, the expected profit of a contrarian portfolio can be approximately decomposed as follows:

$$
E\left(\pi_{t}(p, q)\right)=C(p, q)-O(p, q)-p q \sigma^{2}(\mu),
$$

where

$$
\begin{aligned}
& C(p, q)=\frac{1}{N^{2}} \sum_{i=0}^{p-1} \sum_{j=1}^{q}\left[\mathbf{1}^{\prime} \Gamma_{i+j} \mathbf{1}-\operatorname{tr}\left(\Gamma_{i+j}\right)\right] \\
& O(p, q)=\frac{N-1}{N^{2}} \sum_{i=0}^{p-1} \sum_{j=1}^{q} \operatorname{tr}\left(\Gamma_{i+j}\right), \\
& \sigma^{2}(\mu)=\frac{1}{N} \sum_{i=1}^{N}\left(\mu_{i}-\mu_{m}\right)^{2} .
\end{aligned}
$$

$C(p, q),-O(p, q)$, and $-p q \sigma^{2}(\mu)$ denote the proportions of the expected contrarian profit resulting from cross-autocorrelations, autocorrelations, and the cross-sectional variation in expected returns of individual stocks, respectively. In the appendix, we show how to estimate each of these three components analytically.

As in Lo and MacKinlay (1990), the expected profit of a contrarian portfolio can be decomposed into three components. $C(p, q)$ in equation (6a), which depends on only the off-diagonals of the autocovariance matrixes, $\Gamma_{i+j}$, captures cross-autocorrelations (or so-called lead-lag relations) among the component stocks. Positive (negative) cross-autocorrelation will contribute to the contrarian profit (loss). $O(p, q)$ in equation (6b) is the sum of the $(i+j)$-th autocovariances for all stocks. It is called overreaction if $O(p, q)$ is negative or underreaction if 
$O(p, q)$ is positive. Hence, a negative cross-sectional average of the $(i+j)$-th autocovariances contributes to the contrarian profit. The cross-sectional variation term, $p q \sigma^{2}(\mu)$, in equation (6c) is always positive, since the cross-sectional variation in expected returns of individual stocks is always positive. This suggests that the contribution of $p q \sigma^{2}(\mu)$ to the expected contrarian profit is always negative.

Clearly, contrarian performance depends on the lengths of the ranking period and the lengths of the holding period. Unlike in Lo and MacKinlay (1990) where a stock is classified as a loser or a winner depending on its return in a single period, here the identification of loser and winner depends on the past $p$-period cumulative return. As a result, the performance of a contrarian portfolio will depend on the time-series characteristics of its component stock returns. If the return-generating process is independently and identically distributed (iid) over time, the expected profit of the contrarian portfolio becomes $E\left(\pi_{t}(p, q)\right)=-p q \sigma^{2}(\mu)$, which solely depends on the cross-sectional variation in individual returns along with the lengths of the ranking and holding horizons. The expected profit of the contrarian portfolio per period is:

$$
\frac{E\left(\pi_{t}(p, q)\right)}{q}=-p \sigma^{2}(\mu)
$$

which is always negative. That is, in this case, a momentum strategy is always profitable. In addition, this suggests that the momentum strategy will be more profitable (in terms of the magnitude of the profit per holding period) if a longer ranking horizon is adopted. The reason is that when stock returns are assumed to be iid, the weights assigned to each of the winner and the loser stocks are proportional to the lengths of the ranking horizon.

For a contrarian strategy to be profitable, it is necessary that stock returns must exhibit time-series predictability. Only if the persistence of positive cross-autocorrelations and/or negative autocorrelations dominates the cross-sectional variation in expected returns can a contrarian strategy be profitable. From equation (6), it is clear that the determination of contrarian profits is very complicated. It not only depends on cross-autocorrelations, autocorrelations, and the cross-sectional variation in expected returns, but it also depends on the lengths of the ranking 
horizon and the holding horizon.

Table 5 presents the percentages of contrarian profits attributed to each of the three components: namely, autocorrelation as measured by $-O(p, q)$ (see Panel A), cross-autocorrelation as measured by $C(p, q)$ (see Panel B), and the cross-sectional variation in expected returns as measured by - $p q \sigma^{2}(\mu)$ (see Panel C) across various ranking and holding horizons. Panel D of Table 5 reports the percentages of contrarian profits due to time-series predictability. These percentages are simply the sum of the corresponding numbers in Panel A and Panel B (i.e., $-O(p, q)$ $+C(p, q))$.

\section{[Put Table 5 about here]}

To generate contrarian profits, the sum of the cross-autocorrelation component (i.e., the lead-lag component) and the autocorrelation component (i.e., the overreaction component) must be greater than the cross-sectional variation in expected returns. The results in Table 5 show that this is indeed the case. In particular, the results show that, on average, the time-series predictability (autocorrelation + cross-autocorrelation) accounts for $200.16 \%$ of the contrarian profits for a one-month holding horizon, and up to $499.41 \%$ for a six-month holding horizon. Even for holding horizons longer than one year, the time-series predictability still dominates the cross-sectional variation in expected returns by accounting for more than $200 \%$ of the average contrarian profits.

By comparing the results in Panel A to those in Panel B, we can see that, for most strategies, the cross-autocorrelation (i.e., the lead-lag) component explains more than the autocorrelation (i.e., the overreaction) component. However, the autocorrelation component is larger than the cross-autocorrelation component for ranking and holding horizons lasting between six months and one year. In addition, the contribution of the autocorrelation component is negative for a few strategies, especially for strategies based on ranking horizons longer than nine months and holding horizons lasting one month. In contrast, with only one exception, the cross-autocorrelation component is positive for almost all strategies. Also, for holding horizons shorter than one year, there is a tendency that the "lead-lag" component increases as the length of the ranking horizon 
increases. On average, the "lead-lag” component surpasses the "overreaction” component for most holding horizons, suggesting that contrarian profits in Japan are mainly attributed to the lead-lag relations among stocks.

\subsection{Are contrarian profits normal compensation for bearing risk?}

Since Lo and MacKinlay (1990) do not assume any asset-pricing model as the underlying return-generating process, the sources of contrarian profits due to cross-autocorrelation (or to the lead-lag relation) are unknown. Jegadeesh and Titman (1995) decompose the predictability of a contrarian/momentum portfolio into common-factor and firm-specific components, but their model is not designed to explain the extent to which contrarian profits are reasonable compensation for bearing risk. Also, they do not provide a factor explanation for their multi-period results. In this section, we propose an alternative method to decompose the profitability of a contrarian portfolio to examine if the contrarian profitability documented above is compensation for bearing risk. To measure the risk, we need an asset-pricing model as our benchmark. Daniel et al. (2001) report that while the CAPM cannot explain the returns for their 25 size/book-to-market portfolios, the Fama-French three-factor model appears to be able to do so. We therefore investigate whether the contrarian profitability documented above can be explained by the Fama-French three-factor model as follows.

$$
R_{i t}=a_{i}+b_{i} R_{M k t, t}+c_{i} S M B_{t}+d_{i} H M L_{t}+e_{i t}
$$

where $R_{i t}$ is the excess return for security $i, R_{M k t, t}$ denotes the monthly return on the value-weighted market index of all stocks listed on the Tokyo Stock Exchange in excess of the risk-free rate and $S M B_{t}$ and $H M L_{t}$ are, respectively, the Fama-French (1993) size and book-to-market equity factors. More specifically, $R_{H M L}$ is the difference between the return on the portfolio of high (the top 30\%) book-to-market stocks and the return on the portfolio of low (the bottom 30\%) book-to-market stocks (HML, high minus low). $R_{S M B}$ is the difference between the return on the portfolio of small (the bottom 50\%) stocks and the return on the portfolio of large (the top 50\%) 
stocks ( $S M B$, small minus big). $R_{M k t}$ is the return on the market portfolio. ${ }^{7}$

The Fama-French three-factor model can be compactly represented in a vector form as follows:

$$
R_{t}=a+\beta^{\prime} f_{t}+e_{t}
$$

Then, the profit of a $(p, q)$-contrarian strategy can be written as:

$$
\begin{aligned}
w_{t}(p)^{\prime} R(t, t+q) & =w_{t}(p)^{\prime} a+w_{t}(p)^{\prime} \beta^{\prime} \sum_{j=1}^{q} f_{t+j}+w_{t}(p)^{\prime} \sum_{j=1}^{q} e_{t+j}, \\
& =\pi_{t}^{a}(p, q)+\pi_{t}^{f}(p, q)+\pi_{t}^{e}(p, q),
\end{aligned}
$$

where $\pi_{t}^{a}(p, q) \equiv w_{t}(p)^{\prime} a$ represents the proportion of the contrarian profit due to mispricing, $\pi_{t}^{f}(p, q) \equiv w_{t}(p)^{\prime} \beta^{\prime} \sum_{j=1}^{q} f_{t+j}$ is the proportion of the contrarian profit due to risk bearing, and $\pi_{t}^{e}(p, q) \equiv w_{t}(p)^{\prime} \sum_{j=1}^{q} e_{t+j}$ is the proportion of the contrarian profit due to firm-specific reactions.

By this decomposition, we can examine the extent to which the proportion of the contrarian profit can be explained by the Fama-French three-factor model. As the error terms have zero means and the weights of $w_{t}(p)$ are a function of past returns, a significant $\pi_{t}^{e}(p, q)$ in (9) implies that the firm-specific error components are correlated with past returns. This implies that part of the contrarian profit, if any, is due to autocorrelations and cross-autocorrelations among the firm-specific error components in the Fama-French three-factor model.

Likewise, the measure of $\pi_{t}^{a}(p, q)$ in (9) summarizes the proportion of the contrarian profit that is "abnormal" or is due to pricing errors in the Fama-French three-factor model. Presumably, if the Fama-French three-factor model can explain well the security returns such that the intercepts in (7) are insignificantly different from zero, then $\pi_{t}^{a}(p, q)$ should be close to zero. A positive $\pi_{t}^{a}(p, q)$ would suggest that either (i) the Fama-French three-factor model is not appropriate and

\footnotetext{
${ }^{7}$ The returns on the market portfolio and the Fama-French three factors are adopted from Daniel et al. (2001).
} 
the "weights" of the contrarian portfolio capture the effect of the missing factors, or (ii) the market is inefficient.

Panel A of Table 6 reports the proportion of contrarian profits due to "pricing errors" from the Fama-French three-factor model. The results show that this component is negative for all strategies. However, the pricing-error components are relatively small and diminish as the holding horizon increases. The evidence indicates that contrarian profits are not attributed to the pricing errors in the Fama-French three-factor model. That is, the Fama-French three-factor model can explain contrarian profits reasonably well. Panel B of Table 6 shows that firm-specific error components account for more than 100 percent of contrarian profits for all ranking and holding horizons. In addition, there is a tendency that the contribution of firm-specific error components increases as the length of the ranking and/or holding horizons increases. This implies that firm-specific error terms are correlated with past returns and that serial correlations do not disappear even for holding horizons up to three years. More specifically, contrarian profits are due to autocorrelations or cross-autocorrelations among firm-specific error components in the Fama-French three-factor model. Since the results in Table 5 suggest that contrarian profits are attributed to the lead-lag effect, we may conclude from Tables 5 and 6 that contrarian profits come from cross-autocorrelations (or lead-lag effects) among firm-specific error components.

[Put Table 6 about here]

Overall, from Japanese data, we identify time-series patterns that sharply differ from patterns found in U.S. data and from other international stock-market data. Specifically, we find that contrarian strategies are profitable for horizons ranging from one month to three years, and the major source of the profits is the lead-lag relation among component stocks. That is, we find that contrarian profits are not due to either market overreactions or underreactions. Hence, our results empirically refute the argument that behavioral finance models (Barberis et al., 1998); Daniel et al., 1998; Hong and Stein, 1998) are the prevailing explanation for time-series predictability of stock returns in Japan, and suggest the need to search for a new explanation.

Based on risk decompositions, the results indicate that contrarian profits are not attributed to 
pricing errors in the Fama-French three-factor model, suggesting that the Fama-French three-factor model can explain contrarian profits in Japan. Instead, firm-specific error components are the major source of contrarian profits. That is, cross-autocorrelations among firm-specific error components play the major role in explaining the performance of contrarian profits. We argue in Section 4.1 that the reasons for contrarian profits for long horizons might be due to the value effect. The results in Table 6 appear to support this argument, since the Fama-French three-factor model includes the book-to-market value factor (i.e., the $H M L$ factor) and it can explain contrarian profits well. In particular, contrarian profits are not attributed to pricing errors in the Fama-French three-factor model.

\section{Conclusion}

In this paper, we investigate the performance of contrarian strategies that are formed by buying past losers and selling past winners on the Tokyo Stock Exchange across various ranking and holding horizons ranging from one month to three years over the period from 1975 to 1997. Our empirical results indicate that significant short- and long-term time-series predictability of contrarian portfolios persists in the Japanese stock market. More specifically, contrarian strategies are profitable for ranking and/or holding horizons ranging from one month to three years, especially for very short (one month) and very long (two years or longer) ranking/holding horizons.

In addition, contrarian profits are robust to skipping one month, excluding stocks with extreme past returns, and partitioning the whole period into bull- and bear-market subperiods. After skipping one month or excluding firms with extreme past returns, contrarian profits decrease substantially for short ranking/holding horizons of one year or less, especially for the one-month horizon. However, there is only a marginal effect on contrarian profits for long horizons of two

years or longer. The most surprising result is that contrarian strategies are very profitable in both the bull market of 1975-1989 and the bear market of 1990-1997. We also investigate how the aggregate market performance in the ranking or the holding period affects contrarian profits. In 
general, contrarian strategies perform better when the aggregate market also performs better during either the ranking or the holding period.

Finally, we find that contrarian profits are mainly due to the lead-lag effect (cross-autocorrelation), which is in sharp contrast to the findings by Jegadeesh and Titman (1995) in regard to the U.S. market. Further analysis shows that contrarian profits are not attributed to pricing errors in the Fama-French three-factor model. Instead, they are due to cross-autocorrelations (i.e., the lead-lag effect) among firm-specific error components in the Fama-French three-factor model.

Although most developed stock markets exhibit a medium-term momentum effect with ranking/holding horizons ranging from three months to one year (see, for example, Jegadeesh and Titman, 2001; Rouwenhorst, 1998; Griffin et al., 2003; Chui et al. 2006), not all do. Indeed, we find that the Japanese market exhibits a contrarian effect instead of a momentum effect with ranking/holding horizons ranging from one month to three years. It is of interest to investigate why the Japanese market behaves differently from other developed markets. One of the possible explanations may be the uniqueness of corporate relationships among firms in Japan. In particular, crossholdings are very common among Japanese companies, and these crossholdings among associated firms form a unique corporate relationship called keiretsu (or group). ${ }^{8}$ Cultural differences might be another explanation. Social psychology studies have indicated that Japanese are more collectivist than are Americans (i.e., Americans are more individualist). Social psychology literature has documented that people in more individualist countries tend to be more overconfident and are more prone to commit to self-attribution bias. Daniel et al. (1998) show that overconfidence and self-attribution bias are the major reasons for why the momentum strategy works. There may be additional reasons for why the momentum strategy does not work in Japan. Such analysis is left for future work.

\footnotetext{
${ }^{8}$ Chui et al. (2003) examine whether the corporate ownership structure and the legal system have any effect on the profitability of momentum strategies in Asian markets. In general, they find that the momentum effect is stronger for independent firms than for group-affiliated firms.
} 


\section{Appendix}

This appendix describes analytically how we estimate the average contrarian returns and their

components. Let the holding return $R(t, t+q)$ be approximated by its simple sum of $\sum_{l=1}^{q} R_{t+l}$.

Then, equation (4) can be written as: ${ }^{9}$

$$
\begin{aligned}
\pi_{t}(p, q) & \approx-\frac{1}{N} \sum_{i=1}^{N}\left[\left(\sum_{l=0}^{p-1} R_{i, t-l}\right)\left(\sum_{l=1}^{q} R_{i, t+l}\right)\right]+\frac{1}{N^{2}} \sum_{i} \sum_{j}\left[\left(\sum_{l=0}^{p-1} R_{i, t-l}\right)\left(\sum_{l=1}^{q} R_{j, t+l}\right)\right] \\
& =C_{t}(p, q)-O_{t}(p, q)-\sigma_{t}^{2}(p, q),
\end{aligned}
$$

where

$$
\begin{aligned}
O_{t}(p, q) & =\frac{N-1}{N^{2}} \sum_{i=1}^{N}\left[\sum_{l=0}^{p-1}\left(R_{i, t-l}-\hat{\mu}_{i}\right) \sum_{l=1}^{q}\left(R_{i, t+l}-\hat{\mu}_{i}\right)\right] \\
C_{t}(p, q) & =\frac{1}{N^{2}} \sum_{i} \sum_{j}\left[\sum_{i \neq j}^{p-1}\left(R_{i, t-l}-\hat{\mu}_{i}\right) \sum_{l=1}^{q}\left(R_{i, t+l}-\hat{\mu}_{i}\right)\right] \\
\sigma_{t}^{2}(p, q) & =\frac{p q}{N^{2}}\left(\sum_{i} \sum_{j} \hat{\mu}_{i} \hat{\mu}_{j}-N \sum_{i} \hat{\mu}_{i}^{2}\right) .
\end{aligned}
$$

The estimates of the expected profit, $E(\pi(p, q))$, the autocorrelation component, $O_{t}(p, q)$, the cross-autocorrelation component, $C(p, q)$, and the cross-sectional variation in expected returns, $\sigma^{2}(p, q)$, are calculated as the simple averages of the return realizations outlined above. However, because the estimates are calculated based on overlapping data, tests of their significance cannot be performed based on a traditional t-test. We adopt GMM tests, where the standard errors of the estimates are calculated based on the estimates of Newey and West (1987) that correct for serial correlation and conditional heteroscedasticity.

${ }^{9}$ This is true when logarithm returns are used. 


\section{References}

Alexander, G.J., 2000. On back-testing ‘zero-investment’ strategies. Journal of Business 73, 255-278.

Bacmann, J.F., Dubois, M., 1998. Contrarian strategies and cross-autocorrelations in stock returns: Evidence from France. Working paper, www.ssrn.com.

Barberis, N., Shleifer, A., Vishny, R.W., 1998. A model of investor sentiment. Journal of Financial Economics 49, 307-343.

Ball, R., Kothari, S.P., Shanken, J., 1995. Problems in measuring portfolio performance: an application to contrarian investment strategies. Journal of Financial Economics 38, 79-107.

Chan, K.C., 1988. On contrarian investment strategy. Journal of Business 61, 147-163.

Chan, L.K.C., Hamao, Y., Lakonishok, J., 1991. Fundamentals and stock returns in Japan. Journal of Finance 46, 1739-1764.

Chan, L.K.C., Jegadeesh, N., Lakonishok, J., 1996. Momentum strategies. Journal of Finance 51, 1681-1713.

Chui, A.C.W., Titman, S., Wei, K.C.J., 2003. Momentum, legal systems, and ownership structure: An analysis of Asian stock markets. Working paper, University of Texas at Austin.

Chui, A.C.W., Titman, S., Wei, K.C.J., 2006. Individualism and momentum around the world. Working paper, University of Texas at Austin and the conference paper at the 2006 AFA annual meetings.

Chopra, N., Lakonishok, J., Ritter, J., 1992. Measuring abnormal returns: Do stocks overreact? Journal of Financial Economics 31, 235-268.

Conrad, J., Gultekin, M.N., Kaul, G., 1997. Profitability of short-term contrarian strategies: implications for market efficiency. Journal of Business and Economic Statistics 15, 379-386.

Conrad, J., Kaul, G., 1998. An anatomy of trading strategies. Review of Financial Studies 11, 489-519.

Daniel, K., Hirshleifer, D., Subrahmanyam, A., 1998. Investor psychology and security market under- and overreactions. Journal of Finance 53, 1839-1886.

Daniel, K., Titman, S., Wei, K.C.J., 2001. Explaining the cross-section of stock returns in Japan: factors or characteristics? Journal of Finance 56, 743-766.

De Bondt, W.F.M., Thaler, R.H., 1985. Does the stock market overreact? Journal of Finance 40, 793-808.

De Bondt, W.F.M., Thaler, R.H., 1987. Further evidence on investor overreaction and stock market seasonality. Journal of Finance 42, 557-581. 
Dechow, P.M., Sloan, R.G., 1997. Returns to contrarian investment strategies: Tests of naive expectations hypotheses. Journal of Financial Economics 43, 3-27.

Fama, E.F., French, K.R., 1988. Permanent and temporary components of stock prices. Journal of Political Economy 96, 246-273.

Fama, E.F., French, K.R., 1992. The cross-section of expected stock returns. Journal of Finance 47, 427-465.

Fama, E.F., French, K.R., 1993. Common risk factors in the returns on stocks and bonds. Journal of Financial Economics 33, 3-56.

Fama, E.F., French, K.R., 1996. Multifactor explanations of asset pricing anomalies. Journal of Finance 51, 55-84.

Griffin, J.M., Ji, X., Martin, J.S., 2003. Momentum investing and business cycle risk: Evidence from pole to pole. Journal of Finance, 58, 2515-2547.

Grinblatt, M., Keloharju, M., 2000. The investment behavior and performance of various investor types: A study of Finland's unique data set. Journal of Financial Economics 55, 43-67.

Grundy, B.D., Martin, J.S., 2001. Understanding the nature of the risks and the source of the rewards to momentum investing. Review of Financial Studies 14, 29-78.

Hofstede, G., 1991. Culture and Organization: Software of the Mind. McGraw-Hill: London.

Hong, H., Stein, J.C., 1999. A unified theory of underreaction, momentum trading and overreaction in asset markets. Journal of Finance 54, 2143-2184.

Jacobs, B.I., Levy, K.L., 1995. More on long-short strategies,” Financial Analysts Journal 51 (March-April), 88-90.

Jegadeesh, N., 1990. Evidence of predictable behavior of security returns. Journal of Finance 45, 881-898.

Jegadeesh, N.,Titman, S., 1993. Returns to buying winners and selling losers: Implications for stock market efficiency. Journal of Finance 43, 65-91.

Jegadeesh, N., Titman, S., 1995. Overreaction, delayed reaction, and contrarian profits. Review of Financial Studies 8, 973-993.

Jegadeesh, N., Titman, S., 2001. Profitability of momentum strategies: An evaluation of alternative explanations. Journal of Finance 56, 6989-720.

Jegadeesh, N., Titman, S., 2002. Cross-sectional and time-series determinants of momentum returns. Review of Financial Studies 15, 143-157.

Jones, S.L., 1993. Another look at time-varying risk and return in a long-horizon contrarian strategy. Journal of Financial Economics 33, 119-144.

Kang, J.K., Stulz, R.M., 2000. Do banking shocks affect borrowing firm performance? An analysis of the Japanese experience. Journal of Business 73, 1-23. 
Kato, K., 1990. Being a winner in the Tokyo stock market. Journal of Portfolio Management 16, 52-56.

Kitayama, S., Takagi, H., Matsumoto, H., 1995. Causal attribution of success and failure: Cultural psychology of the Japanese self. Japanese Psychological Review 38, 247-280.

Knez, P., Ready, M., 1997. On the robustness of size and book-to-market in cross-sectional regressions. Journal of Finance 52, 1355-1382.

Lakonishok, J., Shleifer, A., Vishny, R.W., 1994. Contrarian investment, extrapolation, and risk. Journal of Finance 49, 1541-1578.

Lee, C.M.C., Swaminathan, B., 2000. Price momentum and trading volume. Journal of Finance 55, 2017-2069.

Lehmann, B., 1990. Fads, martingales and market efficiency. Quarterly Journal of Economics 105, $1-28$.

Liu, W., Strong, N., Xu, X., 1999.The profitability of momentum investing. Journal of Business Finance and Accounting 26, 1043-1091.

Lo, A.W., MacKinlay, A.C., 1990. When are contrarian profits due to overreaction? Review of Financial Studies 2, 175-205.

Moskowitz, T., Grinblatt, M., 1999. Do industries explain momentum? Journal of Finance 54, 1249-1290.

Newey, W.K., West, K.D., 1987. A simple positive definite, heteroscedasticity and autocorrelation consistent covariance matrix. Economstrica 55, 703-705.

Peters, D.J., 1994. A contrarian strategy for growth stock investing: Theoretical foundations and empirical evidence. Journal of Finance 49, 1534-1537.

Poterba, J.M., Summers, L.H., 1988. Mean reversion in stock prices. Journal of Financial Economics 22, 27-59.

Rouwenhorst, K.G., 1998. International momentum strategies. Journal of Finance 53, 267-284.

Rouwenhorst, K.G., 1999. Local return factors and turnover in emerging stock markets. Journal of Finance 54, 1439-1464. 
Table 1

Average monthly profits of contrarian strategies based on different ranking and holding horizons

\begin{tabular}{|c|c|c|c|c|c|c|c|c|}
\hline \multirow{2}{*}{\multicolumn{2}{|c|}{$\begin{array}{c}\text { Ranking horizon } \\
\text { in months (p) }\end{array}$}} & \multicolumn{7}{|c|}{ Holding horizon in months (q) } \\
\hline & & 1 & 3 & 6 & 9 & 12 & 24 & 36 \\
\hline 1 & $\begin{array}{l}\text { Loser } \\
\text { (Buy) }\end{array}$ & $\begin{array}{l}1.977 \\
(4.79)\end{array}$ & $\begin{array}{l}1.364 \\
(3.49)\end{array}$ & $\begin{array}{l}1.263 \\
(3.36)\end{array}$ & $\begin{array}{l}1.211 \\
(3.30)\end{array}$ & $\begin{array}{l}1.186 \\
(3.20)\end{array}$ & $\begin{array}{l}1.278 \\
(3.32)\end{array}$ & $\begin{array}{l}1.300 \\
(3.21)\end{array}$ \\
\hline & $\begin{array}{l}\text { Winner } \\
\text { (Sell) }\end{array}$ & $\begin{array}{l}-0.423 \\
(-1.24)\end{array}$ & $\begin{array}{l}0.365 \\
(1.14)\end{array}$ & $\begin{array}{l}0.734 \\
(2.24)\end{array}$ & $\begin{array}{l}0.869 \\
(2.56)\end{array}$ & $\begin{array}{l}0.918 \\
(2.67)\end{array}$ & $\begin{array}{l}1.049 \\
(2.83)\end{array}$ & $\begin{array}{l}1.110 \\
(2.84)\end{array}$ \\
\hline & $\begin{array}{l}\text { Loser-Winner } \\
\text { (Buy-Sell) }\end{array}$ & $\begin{array}{l}2.400 \\
(8.24)\end{array}$ & $\begin{array}{l}0.999 \\
(5.04)\end{array}$ & $\begin{array}{l}0.529 \\
(3.81)\end{array}$ & $\begin{array}{l}0.342 \\
(3.15)\end{array}$ & $\begin{array}{l}0.268 \\
(2.83)\end{array}$ & $\begin{array}{l}0.229 \\
(3.49)\end{array}$ & $\begin{array}{l}0.190 \\
(3.47)\end{array}$ \\
\hline 3 & $\begin{array}{l}\text { Loser } \\
\text { (Buy) }\end{array}$ & $\begin{array}{l}1.846 \\
(4.03)\end{array}$ & $\begin{array}{l}1.303 \\
(3.05)\end{array}$ & $\begin{array}{l}1.205 \\
(3.02)\end{array}$ & $\begin{array}{l}1.172 \\
(3.05)\end{array}$ & $\begin{array}{l}1.118 \\
(2.93)\end{array}$ & $\begin{array}{l}1.282 \\
(3.27)\end{array}$ & $\begin{array}{l}1.289 \\
(3.13)\end{array}$ \\
\hline & $\begin{array}{l}\text { Winner } \\
\text { (Sell) }\end{array}$ & $\begin{array}{l}-0.102 \\
(-0.32)\end{array}$ & $\begin{array}{l}0.423 \\
(1.30)\end{array}$ & $\begin{array}{l}0.799 \\
(2.40)\end{array}$ & $\begin{array}{l}0.810 \\
(2.36)\end{array}$ & $\begin{array}{l}0.843 \\
(2.43)\end{array}$ & $\begin{array}{l}0.949 \\
(2.55)\end{array}$ & $\begin{array}{l}0.988 \\
(2.51)\end{array}$ \\
\hline & $\begin{array}{l}\text { Loser-Winner } \\
\text { (Buy-Sell) }\end{array}$ & $\begin{array}{l}1.949 \\
(5.33)\end{array}$ & $\begin{array}{l}0.880 \\
(2.94)\end{array}$ & $\begin{array}{l}0.406 \\
(1.77)\end{array}$ & $\begin{array}{l}0.362 \\
(1.99)\end{array}$ & $\begin{array}{l}0.275 \\
(1.75)\end{array}$ & $\begin{array}{l}0.333 \\
(2.30)\end{array}$ & $\begin{array}{l}0.302 \\
(3.33)\end{array}$ \\
\hline 6 & $\begin{array}{l}\text { Loser } \\
\text { (Buy) }\end{array}$ & $\begin{array}{l}1.537 \\
(3.29)\end{array}$ & $\begin{array}{l}1.196 \\
(2.74)\end{array}$ & $\begin{array}{l}1.138 \\
(2.82)\end{array}$ & $\begin{array}{l}1.054 \\
(2.71)\end{array}$ & $\begin{array}{l}1.100 \\
(2.84)\end{array}$ & $\begin{array}{l}1.292 \\
(3.25)\end{array}$ & $\begin{array}{l}1.258 \\
(3.04)\end{array}$ \\
\hline & $\begin{array}{l}\text { Winner } \\
\text { (Sell) }\end{array}$ & $\begin{array}{l}0.108 \\
(0.33)\end{array}$ & $\begin{array}{l}0.606 \\
(1.80)\end{array}$ & $\begin{array}{l}0.768 \\
(2.21)\end{array}$ & $\begin{array}{l}0.758 \\
(2.15)\end{array}$ & $\begin{array}{l}0.748 \\
(2.09)\end{array}$ & $\begin{array}{l}0.890 \\
(2.33)\end{array}$ & $\begin{array}{l}0.875 \\
(2.19)\end{array}$ \\
\hline & $\begin{array}{l}\text { Loser-Winner } \\
\text { (Buy-Sell) }\end{array}$ & $\begin{array}{l}1.429 \\
(3.75)\end{array}$ & $\begin{array}{l}0.589 \\
(1.75)\end{array}$ & $\begin{array}{l}0.370 \\
(1.32)\end{array}$ & $\begin{array}{l}0.296 \\
(1.25)\end{array}$ & $\begin{array}{l}0.352 \\
(1.67)\end{array}$ & $\begin{array}{l}0.402 \\
(2.57)\end{array}$ & $\begin{array}{l}0.383 \\
(3.02)\end{array}$ \\
\hline 9 & $\begin{array}{l}\text { Loser } \\
\text { (Buy) }\end{array}$ & $\begin{array}{l}1.357 \\
(2.98)\end{array}$ & $\begin{array}{l}1.171 \\
(2.71)\end{array}$ & $\begin{array}{l}1.056 \\
(2.62)\end{array}$ & $\begin{array}{l}1.076 \\
(2.74)\end{array}$ & $\begin{array}{l}1.134 \\
(2.91)\end{array}$ & $\begin{array}{l}1.330 \\
(3.28)\end{array}$ & $\begin{array}{l}1.239 \\
(2.95)\end{array}$ \\
\hline & $\begin{array}{l}\text { Winner } \\
\text { (Sell) }\end{array}$ & $\begin{array}{l}0.208 \\
(0.61)\end{array}$ & $\begin{array}{l}0.527 \\
(1.52)\end{array}$ & $\begin{array}{l}0.713 \\
(2.01)\end{array}$ & $\begin{array}{l}0.655 \\
(1.81)\end{array}$ & $\begin{array}{l}0.660 \\
(1.79)\end{array}$ & $\begin{array}{l}0.850 \\
(2.18)\end{array}$ & $\begin{array}{l}0.747 \\
(1.84)\end{array}$ \\
\hline & $\begin{array}{l}\text { Loser-Winner } \\
\text { (Buy-Sell) }\end{array}$ & $\begin{array}{l}1.149 \\
(2.97)\end{array}$ & $\begin{array}{l}0.644 \\
(1.85)\end{array}$ & $\begin{array}{l}0.343 \\
(1.14)\end{array}$ & $\begin{array}{l}0.420 \\
(1.58)\end{array}$ & $\begin{array}{l}0.474 \\
(1.98)\end{array}$ & $\begin{array}{l}0.480 \\
(2.55)\end{array}$ & $\begin{array}{l}0.492 \\
(3.19)\end{array}$ \\
\hline
\end{tabular}




\section{Table 1 (continued)}

\begin{tabular}{|c|c|c|c|c|c|c|c|c|}
\hline \multirow{2}{*}{\multicolumn{2}{|c|}{$\begin{array}{l}\text { Ranking horizon } \\
\text { In months (p) }\end{array}$}} & \multicolumn{7}{|c|}{ Holding horizon in months (q) } \\
\hline & & \multirow{2}{*}{$\begin{array}{c}1 \\
1.225 \\
(2.64)\end{array}$} & \multirow{2}{*}{$\begin{array}{c}3 \\
1.050 \\
(2.42)\end{array}$} & \multirow{2}{*}{$\begin{array}{c}6 \\
1.046 \\
(2.58)\end{array}$} & \multirow{2}{*}{$\begin{array}{c}9 \\
1.080 \\
(2.73)\end{array}$} & \multirow{2}{*}{$\begin{array}{c}12 \\
1.177 \\
(3.00)\end{array}$} & \multirow{2}{*}{$\begin{array}{c}24 \\
1.380 \\
(3.35)\end{array}$} & \multirow{2}{*}{$\begin{array}{c}36 \\
1.220 \\
(2.85)\end{array}$} \\
\hline 12 & $\begin{array}{l}\text { Loser } \\
\text { (Buy) }\end{array}$ & & & & & & & \\
\hline & $\begin{array}{l}\text { Winner } \\
\text { (Sell) }\end{array}$ & $\begin{array}{l}0.322 \\
(0.95)\end{array}$ & $\begin{array}{l}0.547 \\
(1.57)\end{array}$ & $\begin{array}{c}0.632 \\
(1.75)\end{array}$ & $\begin{array}{l}0.597 \\
(1.61)\end{array}$ & $\begin{array}{l}0.600 \\
(1.61)\end{array}$ & $\begin{array}{l}0.864 \\
(2.19)\end{array}$ & $\begin{array}{l}0.700 \\
(1.70)\end{array}$ \\
\hline & $\begin{array}{l}\text { Loser-Winner } \\
\text { (Buy-Sell) }\end{array}$ & $\begin{array}{l}0.903 \\
(2.31)\end{array}$ & $\begin{array}{l}0.503 \\
(1.43)\end{array}$ & $\begin{array}{l}0.414 \\
(1.35)\end{array}$ & $\begin{array}{l}0.483 \\
(1.75)\end{array}$ & $\begin{array}{l}0.577 \\
(2.28)\end{array}$ & $\begin{array}{l}0.516 \\
(2.49)\end{array}$ & $\begin{array}{l}0.521 \\
(3.09)\end{array}$ \\
\hline 24 & $\begin{array}{l}\text { Loser } \\
\text { (Buy) }\end{array}$ & $\begin{array}{l}1.212 \\
(2.69)\end{array}$ & $\begin{array}{l}1.126 \\
(2.65)\end{array}$ & $\begin{array}{l}1.112 \\
(2.67)\end{array}$ & $\begin{array}{l}1.142 \\
(2.74)\end{array}$ & $\begin{array}{l}1.257 \\
(2.98)\end{array}$ & $\begin{array}{l}1.297 \\
(2.95)\end{array}$ & $\begin{array}{l}1.367 \\
(2.97)\end{array}$ \\
\hline & $\begin{array}{l}\text { Winner } \\
\text { (Sell) }\end{array}$ & $\begin{array}{l}0.124 \\
(0.35)\end{array}$ & $\begin{array}{l}0.294 \\
(0.81)\end{array}$ & $\begin{array}{l}0.466 \\
(1.24)\end{array}$ & $\begin{array}{l}0.449 \\
(1.17)\end{array}$ & $\begin{array}{c}0.532 \\
(1.37)\end{array}$ & $\begin{array}{l}0.523 \\
(1.28)\end{array}$ & $\begin{array}{c}0.616 \\
(1.42)\end{array}$ \\
\hline & $\begin{array}{l}\text { Loser-Winner } \\
\text { (Buy-Sell) }\end{array}$ & $\begin{array}{l}1.088 \\
(2.95)\end{array}$ & $\begin{array}{l}0.832 \\
(2.44)\end{array}$ & $\begin{array}{l}0.646 \\
(2.00)\end{array}$ & $\begin{array}{c}0.693 \\
(2.27)\end{array}$ & $\begin{array}{l}0.725 \\
(2.47)\end{array}$ & $\begin{array}{l}0.774 \\
(2.97)\end{array}$ & $\begin{array}{c}0.751 \\
(3.43)\end{array}$ \\
\hline 36 & $\begin{array}{l}\text { Loser } \\
\text { (Buy) }\end{array}$ & $\begin{array}{l}1.221 \\
(2.64)\end{array}$ & $\begin{array}{l}1.162 \\
(2.62)\end{array}$ & $\begin{array}{l}1.158 \\
(2.69)\end{array}$ & $\begin{array}{l}1.151 \\
(2.67)\end{array}$ & $\begin{array}{l}1.175 \\
(2.70)\end{array}$ & $\begin{array}{l}1.415 \\
(3.07)\end{array}$ & $\begin{array}{l}1.427 \\
(2.92)\end{array}$ \\
\hline & $\begin{array}{l}\text { Winner } \\
\text { (Sell) }\end{array}$ & $\begin{array}{l}0.095 \\
(0.27)\end{array}$ & $\begin{array}{l}0.249 \\
(0.69)\end{array}$ & $\begin{array}{l}0.351 \\
(0.94)\end{array}$ & $\begin{array}{l}0.250 \\
(0.66)\end{array}$ & $\begin{array}{l}0.283 \\
(0.73)\end{array}$ & $\begin{array}{l}0.535 \\
(1.28)\end{array}$ & $\begin{array}{l}0.554 \\
(1.21)\end{array}$ \\
\hline & $\begin{array}{l}\text { Loser-Winner } \\
\text { (Buy-Sell) }\end{array}$ & $\begin{array}{l}1.126 \\
(3.06)\end{array}$ & $\begin{array}{l}0.913 \\
(2.63)\end{array}$ & $\begin{array}{l}0.807 \\
(2.48)\end{array}$ & $\begin{array}{l}0.902 \\
(2.90)\end{array}$ & $\begin{array}{l}0.893 \\
(3.01)\end{array}$ & $\begin{array}{l}0.880 \\
(3.22)\end{array}$ & $\begin{array}{l}0.873 \\
(3.42)\end{array}$ \\
\hline
\end{tabular}

This table reports the average monthly returns (in percent) of contrarian portfolios based on a $p$-month ranking period and a $q$-month holding period. At the end of each month, all stocks listed on the Tokyo Stock Exchange (TSE) during the 1975-1997 period are ranked in an ascending order based on the past $p$-month cumulative returns. Stocks in the bottom decile of past returns are assigned to the "Loser" (or "Buy") portfolio and in the top decile as the "Winner" (or "Sell") portfolio. These portfolios are equally weighted and are held for $q$ months. To increase the power of our tests, overlapping portfolios as described in Jegadeesh and Titman (1993) are constructed. The contrarian portfolio is the zero-cost, loser minus winner (denoted as "Loser - Winner or "Buy - Sell") portfolio. The corresponding t-statistics adjusted for heteroscedasticity and autocorrelation are reported in parentheses. 
Table 2

Average monthly profits of contrarian strategies based on symmetric ranking and holding horizons: Robustness checks and subperiod analyses

\begin{tabular}{|c|c|c|c|c|c|c|c|}
\hline & \multicolumn{7}{|c|}{ Ranking horizon = Holding horizon $(p=q)$ in months } \\
\hline & 1 & 3 & 6 & 9 & 12 & 24 & 36 \\
\hline \multicolumn{8}{|c|}{ Panel A: Skipping one month } \\
\hline $\begin{array}{l}\text { Loser } \\
\text { (Buy) }\end{array}$ & $\begin{array}{l}0.993 \\
(2.37)\end{array}$ & $\begin{array}{l}0.928 \\
(2.24)\end{array}$ & $\begin{array}{l}0.923 \\
(2.36)\end{array}$ & $\begin{array}{l}1.067 \\
(2.76)\end{array}$ & $\begin{array}{l}1.102 \\
(2.85)\end{array}$ & $\begin{array}{l}1.241 \\
(2.83)\end{array}$ & $\begin{array}{l}1.344 \\
(2.74)\end{array}$ \\
\hline $\begin{array}{l}\text { Winner } \\
\text { (Sell) }\end{array}$ & $\begin{array}{l}0.378 \\
(1.13)\end{array}$ & $\begin{array}{l}0.719 \\
(2.16)\end{array}$ & $\begin{array}{l}0.861 \\
(2.42)\end{array}$ & $\begin{array}{l}0.731 \\
(1.99)\end{array}$ & $\begin{array}{l}0.610 \\
(1.62)\end{array}$ & $\begin{array}{l}0.504 \\
(1.23)\end{array}$ & $\begin{array}{l}0.485 \\
(1.05)\end{array}$ \\
\hline $\begin{array}{l}\text { Loser-Winner } \\
\text { (Buy-Sell) }\end{array}$ & $\begin{array}{l}0.616 \\
(2.21)\end{array}$ & $\begin{array}{l}0.209 \\
(0.76)\end{array}$ & $\begin{array}{l}0.062 \\
(0.23)\end{array}$ & $\begin{array}{l}0.335 \\
(1.29)\end{array}$ & $\begin{array}{l}0.492 \\
(1.99)\end{array}$ & $\begin{array}{l}0.738 \\
(2.88)\end{array}$ & $\begin{array}{l}0.859 \\
(3.40)\end{array}$ \\
\hline \multicolumn{8}{|c|}{ Panel B: Trimming the top and bottom 2.5\% extreme observations } \\
\hline $\begin{array}{l}\text { Loser } \\
\text { (Buy) }\end{array}$ & $\begin{array}{l}1.451 \\
(4.58)\end{array}$ & $\begin{array}{l}1.011 \\
(3.09)\end{array}$ & $\begin{array}{l}0.952 \\
(3.07)\end{array}$ & $\begin{array}{l}0.881 \\
(2.92)\end{array}$ & $\begin{array}{l}0.965 \\
(3.18)\end{array}$ & $\begin{array}{l}1.071 \\
(3.14)\end{array}$ & $\begin{array}{l}1.165 \\
(3.07)\end{array}$ \\
\hline $\begin{array}{l}\text { Winner } \\
\text { (Sell) }\end{array}$ & $\begin{array}{l}-0.020 \\
(-0.07)\end{array}$ & $\begin{array}{l}0.541 \\
(2.11)\end{array}$ & $\begin{array}{l}0.774 \\
(2.82)\end{array}$ & $\begin{array}{l}0.682 \\
(2.38)\end{array}$ & $\begin{array}{l}0.638 \\
(2.15)\end{array}$ & $\begin{array}{l}0.538 \\
(1.64)\end{array}$ & $\begin{array}{l}0.574 \\
(1.55)\end{array}$ \\
\hline $\begin{array}{l}\text { Loser-Winner } \\
\text { (Buy-Sell) }\end{array}$ & $\begin{array}{l}1.470 \\
(6.95)\end{array}$ & $\begin{array}{l}0.470 \\
(2.14)\end{array}$ & $\begin{array}{l}0.177 \\
(0.88)\end{array}$ & $\begin{array}{l}0.199 \\
(1.05)\end{array}$ & $\begin{array}{l}0.327 \\
(1.77)\end{array}$ & $\begin{array}{l}0.533 \\
(2.79)\end{array}$ & $\begin{array}{l}0.591 \\
(3.21)\end{array}$ \\
\hline \multicolumn{8}{|c|}{ Panel C: the 1975-1989 subperiod } \\
\hline $\begin{array}{l}\text { Loser } \\
\text { (Buy) }\end{array}$ & $\begin{array}{l}2.632 \\
(7.39)\end{array}$ & $\begin{array}{l}2.133 \\
(5.70)\end{array}$ & $\begin{array}{l}1.732 \\
(4.85)\end{array}$ & $\begin{array}{l}1.675 \\
(4.91)\end{array}$ & $\begin{array}{l}1.839 \\
(5.45)\end{array}$ & $\begin{array}{l}1.808 \\
(4.70)\end{array}$ & $\begin{array}{l}1.940 \\
(4.61)\end{array}$ \\
\hline $\begin{array}{l}\text { Winner } \\
\text { (Sell) }\end{array}$ & $\begin{array}{l}0.717 \\
(2.31)\end{array}$ & $\begin{array}{l}1.253 \\
(3.97)\end{array}$ & $\begin{array}{l}1.667 \\
(4.89)\end{array}$ & $\begin{array}{l}1.514 \\
(4.09)\end{array}$ & $\begin{array}{l}1.308 \\
(3.44)\end{array}$ & $\begin{array}{l}0.997 \\
(2.39)\end{array}$ & $\begin{array}{l}1.288 \\
(2.49)\end{array}$ \\
\hline $\begin{array}{l}\text { Loser-Winner } \\
\text { (Buy-Sell) }\end{array}$ & $\begin{array}{l}1.915 \\
(6.09)\end{array}$ & $\begin{array}{l}0.880 \\
(2.54)\end{array}$ & $\begin{array}{l}0.065 \\
(0.19)\end{array}$ & $\begin{array}{l}0.162 \\
(0.46)\end{array}$ & $\begin{array}{l}0.531 \\
(1.53)\end{array}$ & $\begin{array}{l}0.810 \\
(2.02)\end{array}$ & $\begin{array}{l}0.651 \\
(1.43)\end{array}$ \\
\hline \multicolumn{8}{|c|}{ Panel D: the 1990-1997 subperiod } \\
\hline $\begin{array}{l}\text { Loser } \\
\text { (Buy) }\end{array}$ & $\begin{array}{l}0.541 \\
(0.76)\end{array}$ & $\begin{array}{l}-0.229 \\
(-0.31)\end{array}$ & $\begin{array}{c}-0.0240 \\
(-0.03)\end{array}$ & $\begin{array}{l}-0.117 \\
(-0.16)\end{array}$ & $\begin{array}{l}-0.080 \\
(-0.10)\end{array}$ & $\begin{array}{l}0.437 \\
(0.43)\end{array}$ & $\begin{array}{l}1.760 \\
(1.01)\end{array}$ \\
\hline $\begin{array}{l}\text { Winner } \\
\text { (Sell) }\end{array}$ & $\begin{array}{l}-1.885 \\
(-3.42)\end{array}$ & $\begin{array}{l}-0.865 \\
(-1.64)\end{array}$ & $\begin{array}{l}-0.754 \\
(-1.31)\end{array}$ & $\begin{array}{l}-0.803 \\
(-1.32)\end{array}$ & $\begin{array}{l}-0.668 \\
(-1.05)\end{array}$ & $\begin{array}{l}-0.398 \\
(-0.51)\end{array}$ & $\begin{array}{l}0.288 \\
(0.25)\end{array}$ \\
\hline $\begin{array}{l}\text { Loser-Winner } \\
\text { (Buy-Sell) }\end{array}$ & $\begin{array}{l}2.426 \\
(5.39)\end{array}$ & $\begin{array}{l}0.636 \\
(1.46)\end{array}$ & $\begin{array}{l}0.730 \\
(1.89)\end{array}$ & $\begin{array}{l}0.686 \\
(2.04)\end{array}$ & $\begin{array}{l}0.589 \\
(1.76)\end{array}$ & $\begin{array}{l}0.835 \\
(1.91)\end{array}$ & $\begin{array}{l}1.471 \\
(2.09)\end{array}$ \\
\hline $\begin{array}{l}\text { This table repo } \\
\text { holding horizo } \\
\text { month after the } \\
\text { are ranked in th } \\
1975-1989 \text { and } \\
\text { reported in par }\end{array}$ & 997. The & y returl & percent) & trarian & $\begin{array}{l}\text { lios for } \\
\text { ts for } p\end{array}$ & length $\mathrm{r}$ & $\begin{array}{l}g \text { and } \\
\text { med one } \\
\text { firms that } \\
\text { subperiods } \\
\text { ity are }\end{array}$ \\
\hline
\end{tabular}


Table 3

Average monthly profits of contrarian strategies under different market conditions

\begin{tabular}{|c|c|c|c|c|c|c|c|}
\hline & \multicolumn{7}{|c|}{ Holding horizon in months (q) } \\
\hline & 1 & 3 & 6 & 9 & 12 & 24 & 36 \\
\hline \multicolumn{8}{|c|}{ Panel A: Up market in the holding horizon, Mkt $(\mathrm{t}, \mathrm{t}+\mathrm{q})>0$ with $\mathrm{p}=\mathrm{q}$} \\
\hline $\begin{array}{l}\text { Loser } \\
\text { (Buy) }\end{array}$ & $\begin{array}{c}5.516 \\
(13.30)\end{array}$ & $\begin{array}{c}3.551 \\
(15.32)\end{array}$ & $\begin{array}{c}2.689 \\
(15.20)\end{array}$ & $\begin{array}{c}2.206 \\
(16.91)\end{array}$ & $\begin{array}{c}2.071 \\
(19.15)\end{array}$ & $\begin{array}{c}1.953 \\
(24.68)\end{array}$ & $\begin{array}{c}1.902 \\
(24.49)\end{array}$ \\
\hline $\begin{array}{l}\text { Winner } \\
\text { (Sell) }\end{array}$ & $\begin{array}{l}2.603 \\
(8.72)\end{array}$ & $\begin{array}{c}2.448 \\
(12.98)\end{array}$ & $\begin{array}{c}2.017 \\
(14.12)\end{array}$ & $\begin{array}{c}1.722 \\
(15.58)\end{array}$ & $\begin{array}{c}1.494 \\
(16.17)\end{array}$ & $\begin{array}{c}1.079 \\
(14.76)\end{array}$ & $\begin{array}{c}1.054 \\
(16.00)\end{array}$ \\
\hline $\begin{array}{l}\text { Loser-Winner } \\
\text { (Buy-Sell) }\end{array}$ & $\begin{array}{l}2.913 \\
(7.30)\end{array}$ & $\begin{array}{l}1.103 \\
(4.71)\end{array}$ & $\begin{array}{l}0.672 \\
(4.15)\end{array}$ & $\begin{array}{l}0.484 \\
(3.58)\end{array}$ & $\begin{array}{l}0.576 \\
(5.06)\end{array}$ & $\begin{array}{c}0.874 \\
(12.94)\end{array}$ & $\begin{array}{c}0.848 \\
(15.65)\end{array}$ \\
\hline \multicolumn{8}{|c|}{ Panel B: Down market in the holding horizon, $\operatorname{Mkt}(\mathrm{t}, \mathrm{t}+\mathrm{q})<0$ with $\mathrm{p}=\mathrm{q}$} \\
\hline $\begin{array}{l}\text { Loser } \\
\text { (Buy) }\end{array}$ & $\begin{array}{l}-3.808 \\
(-8.47)\end{array}$ & $\begin{array}{l}-2.709 \\
(-8.95)\end{array}$ & $\begin{array}{l}-2.264 \\
(-9.47)\end{array}$ & $\begin{array}{l}-1.864 \\
(-8.62)\end{array}$ & $\begin{array}{l}-1.549 \\
(-7.67)\end{array}$ & $\begin{array}{l}-0.650 \\
(-6.10)\end{array}$ & $\begin{array}{l}-0.262 \\
(-2.76)\end{array}$ \\
\hline $\begin{array}{l}\text { Winner } \\
\text { (Sell) }\end{array}$ & $\begin{array}{c}-5.368 \\
(-12.42)\end{array}$ & $\begin{array}{c}-3.038 \\
(-12.42)\end{array}$ & $\begin{array}{l}-1.795 \\
(-7.96)\end{array}$ & $\begin{array}{c}-1.772 \\
(-10.36)\end{array}$ & $\begin{array}{c}-1.694 \\
(-11.68)\end{array}$ & $\begin{array}{l}-1.045 \\
(-9.61)\end{array}$ & $\begin{array}{c}-0.899 \\
(-13.49)\end{array}$ \\
\hline $\begin{array}{l}\text { Loser-Winner } \\
\text { (Buy-Sell) }\end{array}$ & $\begin{array}{l}1.560 \\
(3.95)\end{array}$ & $\begin{array}{l}0.329 \\
(1.28)\end{array}$ & $\begin{array}{l}-0.468 \\
(-2.05)\end{array}$ & $\begin{array}{l}-0.092 \\
(-0.46)\end{array}$ & $\begin{array}{l}0.145 \\
(1.20)\end{array}$ & $\begin{array}{l}0.395 \\
(6.51)\end{array}$ & $\begin{array}{c}0.637 \\
(10.05)\end{array}$ \\
\hline \multicolumn{8}{|c|}{ Panel C: Up market in the ranking horizon with a duration of one year, Mkt(t-12, t)>0 for (12,q)-strategies } \\
\hline $\begin{array}{l}\text { Loser } \\
\text { (Buy) }\end{array}$ & $\begin{array}{c}4.909 \\
(10.38)\end{array}$ & $\begin{array}{c}3.287 \\
(12.56)\end{array}$ & $\begin{array}{c}2.600 \\
(14.82)\end{array}$ & $\begin{array}{c}2.196 \\
(16.55)\end{array}$ & $\begin{array}{c}2.071 \\
(19.15)\end{array}$ & $\begin{array}{c}1.794 \\
(24.50)\end{array}$ & $\begin{array}{c}1.754 \\
(24.29)\end{array}$ \\
\hline $\begin{array}{l}\text { Winner } \\
\text { (Sell) }\end{array}$ & $\begin{array}{c}3.160 \\
(10.16)\end{array}$ & $\begin{array}{c}2.532 \\
(13.34)\end{array}$ & $\begin{array}{c}1.902 \\
(13.42)\end{array}$ & $\begin{array}{c}1.630 \\
(14.76)\end{array}$ & $\begin{array}{c}1.494 \\
(16.17)\end{array}$ & $\begin{array}{c}1.263 \\
(18.04)\end{array}$ & $\begin{array}{c}1.263 \\
(19.92)\end{array}$ \\
\hline $\begin{array}{l}\text { Loser-Winner } \\
\text { (Buy-Sell) }\end{array}$ & $\begin{array}{l}1.748 \\
(3.53)\end{array}$ & $\begin{array}{l}0.755 \\
(2.70)\end{array}$ & $\begin{array}{l}0.698 \\
(3.95)\end{array}$ & $\begin{array}{l}0.566 \\
(4.05)\end{array}$ & $\begin{array}{l}0.576 \\
(5.06)\end{array}$ & $\begin{array}{l}0.530 \\
(8.28)\end{array}$ & $\begin{array}{l}0.491 \\
(8.73)\end{array}$ \\
\hline \multicolumn{8}{|c|}{ Panel D: Down market in the ranking horizon with a duration of one year, Mkt(t-12, t)<0 for $(12, q)$-strategies } \\
\hline $\begin{array}{l}\text { Loser } \\
\text { (Buy) }\end{array}$ & $\begin{array}{l}-4.780 \\
(-8.68)\end{array}$ & $\begin{array}{l}-2.978 \\
(-9.25)\end{array}$ & $\begin{array}{l}-2.202 \\
(-8.94)\end{array}$ & $\begin{array}{l}-1.854 \\
(-8.69)\end{array}$ & $\begin{array}{l}-1.549 \\
(-7.67)\end{array}$ & $\begin{array}{l}-0.670 \\
(-6.14)\end{array}$ & $\begin{array}{l}-0.326 \\
(-3.43)\end{array}$ \\
\hline $\begin{array}{l}\text { Winner } \\
\text { (Sell) }\end{array}$ & $\begin{array}{l}-4.306 \\
(-9.76)\end{array}$ & $\begin{array}{c}-2.760 \\
(-10.34)\end{array}$ & $\begin{array}{l}-1.820 \\
(-8.33)\end{array}$ & $\begin{array}{c}-1.800 \\
(-10.99)\end{array}$ & $\begin{array}{c}-1.694 \\
(-11.68)\end{array}$ & $\begin{array}{l}-0.958 \\
(-8.39)\end{array}$ & $\begin{array}{c}-0.698 \\
(-10.01)\end{array}$ \\
\hline $\begin{array}{l}\text { Loser-Winner } \\
\text { (Buy-Sell) }\end{array}$ & $\begin{array}{l}-0.474 \\
(-0.76)\end{array}$ & $\begin{array}{l}-0.218 \\
(-0.66)\end{array}$ & $\begin{array}{l}-0.383 \\
(-1.64)\end{array}$ & $\begin{array}{l}-0.055 \\
(-0.32)\end{array}$ & $\begin{array}{l}0.145 \\
(1.20)\end{array}$ & $\begin{array}{l}0.289 \\
(3.70)\end{array}$ & $\begin{array}{l}0.373 \\
(6.08)\end{array}$ \\
\hline
\end{tabular}


Table 3 (continued)

\begin{tabular}{|c|c|c|c|c|c|c|c|}
\hline $\begin{array}{l}\text { Loser } \\
\text { (Buy) }\end{array}$ & $\begin{array}{c}4.979 \\
(11.10)\end{array}$ & $\begin{array}{c}3.702 \\
(13.79)\end{array}$ & $\begin{array}{c}3.003 \\
(15.95)\end{array}$ & $\begin{array}{c}2.525 \\
(19.22)\end{array}$ & $\begin{array}{c}2.361 \\
(22.81)\end{array}$ & $\begin{array}{c}1.979 \\
(25.79)\end{array}$ & $\begin{array}{l}1.902 \\
(24.49)\end{array}$ \\
\hline $\begin{array}{l}\text { Winner } \\
\text { (Sell) }\end{array}$ & $\begin{array}{l}3.006 \\
(9.24)\end{array}$ & $\begin{array}{c}2.223 \\
(10.77)\end{array}$ & $\begin{array}{c}1.607 \\
(10.53)\end{array}$ & $\begin{array}{c}1.294 \\
(10.78)\end{array}$ & $\begin{array}{c}1.221 \\
(12.65)\end{array}$ & $\begin{array}{c}0.998 \\
(13.33)\end{array}$ & $\begin{array}{c}1.054 \\
(16.00)\end{array}$ \\
\hline $\begin{array}{l}\text { Loser-Winner } \\
\text { (Buy-Sell) }\end{array}$ & $\begin{array}{l}1.973 \\
(4.37)\end{array}$ & $\begin{array}{l}1.478 \\
(4.86)\end{array}$ & $\begin{array}{l}1.396 \\
(7.26)\end{array}$ & $\begin{array}{l}1.231 \\
(9.09)\end{array}$ & $\begin{array}{c}1.140 \\
(11.00)\end{array}$ & $\begin{array}{c}0.981 \\
(14.65)\end{array}$ & $\begin{array}{c}0.848 \\
(15.65)\end{array}$ \\
\hline
\end{tabular}

Panel F: Down market in th ranking period with a duration of three years, Mkt(t-36, t)<0 for (36,q)-strategies

$\begin{array}{lccccccc}\text { Loser } & -4.575 & -3.082 & -2.210 & -1.887 & -1.498 & -0.566 & -0.262 \\ \text { (Buy) } & (-8.17) & (-9.12) & (-8.24) & (-8.23) & (-7.02) & (-4.96) & (-2.76) \\ \text { Winner } & -4.395 & -2.850 & -1.894 & -1.834 & -1.724 & -1.100 & -0.899 \\ \text { (Sell) } & (-9.89) & (-11.56) & (-10.18) & (-12.17) & (-12.76) & (-9.91) & (-13.49) \\ \text { Loser-Winner } & -0.180 & -0.232 & -0.317 & -0.053 & 0.226 & 0.534 & 0.637 \\ \text { (Buy-Sell) } & (-0.30) & (-0.71) & (-1.35) & (-0.28) & (1.45) & (7.71) & (10.05)\end{array}$

This table reports the average monthly returns (in percent) of contrarian portfolios under various market conditions. Portfolios are formed as in Table 1. Panels A and B report the profits of symmetric contrarian $(p=q)$ strategies when the market index return during the holding period, $\mathrm{Mkt}(\mathrm{t}, \mathrm{t}+\mathrm{q})$, is positive and negative, respectively. The market index is the value-weighted index of all stocks listed on the TSE. Panels C and D report the results for the (12,q)-strategies with positive and negative ranking-period market returns, respectively, while Panels E and F present the corresponding results for the (36,q)-strategies. The corresponding t-statistics adjusted for autocorrelation and heteroscedasticity are reported in parentheses. 
Table 4

Performance of contrarian portfolios in event time

\begin{tabular}{cccccccccccc}
\hline Month t & Return & t stat. & Cum ret & Month t & Return & t stat. & Cum ret & Month t & Return & t stat. & Cum ret \\
\hline Panel A: $\mathrm{p}=6$ & & & & & & & & & & \\
1 & 1.429 & $(4.00)$ & 1.429 & 13 & 0.580 & $(2.27)$ & 2.194 & 25 & 0.424 & $(1.70)$ & 5.933 \\
2 & 0.109 & $(0.31)$ & 1.538 & 14 & 0.488 & $(1.84)$ & 2.682 & 26 & 0.500 & $(1.89)$ & 6.433 \\
3 & -0.123 & $(-0.37)$ & 1.415 & 15 & 0.561 & $(2.06)$ & 3.243 & 27 & 0.255 & $(0.96)$ & 6.688 \\
4 & -0.009 & $(-0.03)$ & 1.406 & 16 & 0.577 & $(1.94)$ & 3.820 & 28 & 0.352 & $(1.46)$ & 7.040 \\
5 & -0.036 & $(-0.11)$ & 1.370 & 17 & 0.323 & $(1.12)$ & 4.143 & 29 & 0.278 & $(1.17)$ & 7.318 \\
6 & -0.036 & $(-0.11)$ & 1.334 & 18 & 0.135 & $(0.47)$ & 4.278 & 30 & 0.265 & $(1.14)$ & 7.583 \\
7 & -0.296 & $(-0.94)$ & 1.038 & 19 & 0.070 & $(0.25)$ & 4.348 & 31 & 0.180 & $(0.80)$ & 7.763 \\
8 & -0.191 & $(-0.61)$ & 0.847 & 20 & 0.105 & $(0.38)$ & 4.453 & 32 & 0.052 & $(0.24)$ & 7.815 \\
9 & -0.068 & $(-0.21)$ & 0.779 & 21 & 0.227 & $(0.82)$ & 4.680 & 33 & 0.142 & $(0.64)$ & 7.957 \\
10 & 0.032 & $(0.11)$ & 0.811 & 22 & 0.209 & $(0.75)$ & 4.889 & 34 & 0.238 & $(1.13)$ & 8.195 \\
11 & 0.301 & $(1.11)$ & 1.112 & 23 & 0.342 & $(1.25)$ & 5.231 & 35 & 0.223 & $(1.03)$ & 8.418 \\
12 & 0.502 & $(1.85)$ & 1.614 & 24 & 0.278 & $(1.10)$ & 5.509 & 36 & 0.392 & $(1.85)$ & 8.810
\end{tabular}

Panel B: $p=24$

$\begin{array}{llllllllllll}1 & 1.088 & (2.74) & 1.088 & 13 & 0.621 & (1.91) & 7.075 & 25 & 0.559 & (2.25) & 14.494 \\ 2 & 0.596 & (1.54) & 1.684 & 14 & 0.593 & (1.85) & 7.668 & 26 & 0.616 & (2.51) & 15.110 \\ 3 & 0.439 & (1.13) & 2.123 & 15 & 0.657 & (2.03) & 8.325 & 27 & 0.497 & (2.10) & 15.607 \\ 4 & 0.323 & (0.84) & 2.446 & 16 & 0.617 & (1.88) & 8.942 & 28 & 0.583 & (2.49) & 16.190 \\ 5 & 0.331 & (0.85) & 2.777 & 17 & 0.566 & (1.79) & 9.508 & 29 & 0.390 & (1.73) & 16.580 \\ 6 & 0.370 & (1.00) & 3.147 & 18 & 0.673 & (2.06) & 10.181 & 30 & 0.446 & (1.91) & 17.026 \\ 7 & 0.385 & (1.08) & 3.532 & 19 & 0.516 & (1.70) & 10.697 & 31 & 0.478 & (2.13) & 17.504 \\ 8 & 0.503 & (1.36) & 4.035 & 20 & 0.580 & (1.99) & 11.277 & 32 & 0.518 & (2.36) & 18.022 \\ 9 & 0.593 & (1.63) & 4.628 & 21 & 0.615 & (2.30) & 11.892 & 33 & 0.486 & (2.19) & 18.508 \\ 10 & 0.645 & (1.82) & 5.273 & 22 & 0.658 & (2.49) & 12.550 & 34 & 0.449 & (2.02) & 18.957 \\ 11 & 0.667 & (1.95) & 5.940 & 23 & 0.658 & (2.63) & 13.208 & 35 & 0.425 & (1.90) & 19.382 \\ 12 & 0.514 & (1.56) & 6.454 & 24 & 0.727 & (3.05) & 13.935 & 36 & 0.435 & (1.90) & 18.817\end{array}$

The contrarian portfolios are formed based on the past $\mathrm{p}$-month ( $\mathrm{p}=6$ and 24$)$ returns. All stocks are ranked in an ascending order, and the equally weighted portfolio of stocks in the lowest decile is the "Loser" ("Buy") portfolio and the equally weighted portfolio of stocks in the highest decile is the "Winner" ("Sell”) portfolio. This table reports the average return of the Loser-minus-Winner (or Buy-minus-Sell) portfolio in each month following the formation period. $t$ is the month after the portfolio formation. The sample period is from 1975 to 1997. The t-statistics are calculated based on the Newey-West (1987) adjustment for autocorrelation and heteroscedasticity. 
Table 5

Decomposition of contrarian profits for different ranking and holding horizons

\begin{tabular}{|c|c|c|c|c|c|c|c|}
\hline \multirow{2}{*}{$\begin{array}{c}\text { Ranking horizon } \\
\text { in months (p) }\end{array}$} & \multicolumn{7}{|c|}{ Holding horizon in months (q) } \\
\hline & 1 & 3 & 6 & 9 & 12 & 24 & 36 \\
\hline \multicolumn{8}{|c|}{ Panel A: Autocorrelation } \\
\hline 1 & 24.10 & 37.84 & 103.79 & 30.14 & 46.23 & 65.38 & 10.15 \\
\hline 3 & 34.68 & 18.96 & 147.52 & 23.71 & 166.54 & 54.42 & -11.40 \\
\hline 6 & 51.84 & 107.23 & 179.14 & 265.86 & 320.75 & -8.59 & -1.81 \\
\hline 9 & -25.65 & -28.23 & 474.95 & 291.24 & 230.53 & -60.47 & 5.01 \\
\hline 12 & -64.27 & 77.92 & 438.26 & 222.94 & 203.78 & -52.87 & 30.84 \\
\hline 24 & -19.00 & 36.61 & 6.00 & -31.53 & -6.71 & 6.04 & 113.10 \\
\hline 36 & -204.48 & -257.76 & -84.93 & 17.30 & 96.74 & 141.08 & 198.11 \\
\hline Average & -28.97 & -1.06 & 180.68 & 117.10 & 151.12 & 20.71 & 49.15 \\
\hline
\end{tabular}

Panel B: Cross Autocorrelation

\begin{tabular}{crrrrrrr}
\hline 1 & 82.41 & 76.56 & 20.86 & 111.14 & 106.24 & 91.63 & 155.69 \\
3 & 80.22 & 111.19 & 17.71 & 173.78 & 62.20 & 137.27 & 210.97 \\
6 & 79.42 & 73.21 & 141.81 & 264.66 & -20.05 & 236.55 & 221.52 \\
9 & 188.68 & 282.71 & 718.13 & 170.10 & 53.58 & 299.99 & 217.50 \\
12 & 269.09 & 412.24 & 144.85 & 125.67 & 68.87 & 291.06 & 192.54 \\
24 & 266.98 & 292.00 & 386.25 & 394.78 & 323.04 & 253.11 & 130.28 \\
36 & 637.09 & 994.63 & 801.53 & 495.87 & 309.61 & 177.79 & 123.18 \\
\hline Average & 229.13 & 320.36 & 318.74 & 248.00 & 129.07 & 212.48 & 178.81 \\
\hline
\end{tabular}

Panel C: Cross-sectional variation

\begin{tabular}{crrrrrrr}
\hline 1 & -6.51 & -14.40 & -24.66 & -41.29 & -52.47 & -57.02 & -65.85 \\
3 & -14.90 & -30.15 & -65.23 & -97.49 & -128.74 & -91.70 & -99.57 \\
6 & -31.26 & -80.45 & -220.95 & -430.52 & -200.70 & -127.95 & -119.71 \\
9 & -63.03 & -154.48 & -1093.09 & -361.34 & -184.11 & -139.52 & -122.51 \\
12 & -104.82 & -390.17 & -483.11 & -248.62 & -172.65 & -138.19 & -123.38 \\
24 & -147.98 & -228.61 & -292.25 & -263.25 & -216.33 & -159.14 & -143.38 \\
36 & -332.61 & -636.87 & -616.60 & -413.17 & -306.35 & -218.87 & -221.30 \\
\hline Average & -100.16 & -219.30 & -399.41 & -265.10 & -180.19 & -133.20 & -127.96 \\
\hline
\end{tabular}

Panel D: Autocorrelation + Cross-autocorrelation

\begin{tabular}{crrrrrrr}
\hline 1 & 106.51 & 114.40 & 124.66 & 141.29 & 152.47 & 157.02 & 165.85 \\
3 & 114.90 & 130.15 & 165.23 & 197.49 & 228.74 & 191.70 & 199.57 \\
6 & 131.26 & 180.45 & 320.95 & 530.52 & 300.70 & 227.95 & 219.71 \\
9 & 163.03 & 254.48 & 1193.09 & 461.34 & 284.11 & 239.52 & 222.51 \\
12 & 204.82 & 490.17 & 583.11 & 348.62 & 272.65 & 238.19 & 223.38 \\
24 & 247.98 & 328.61 & 392.25 & 363.25 & 316.33 & 259.14 & 243.38 \\
36 & 432.61 & 736.87 & 716.60 & 513.17 & 406.35 & 318.87 & 321.30 \\
\hline Average & 200.16 & 319.30 & 499.41 & 365.10 & 280.19 & 233.20 & 227.96 \\
\hline
\end{tabular}

This table reports the proportion of contrarian profits in each of the three components decomposed by equation (6). Panel A reports the proportion attributed to autocorrelations (overreactions), Panel B to cross-autocorrelations (lead-lag effects), and Panel C to cross-sectional variations in expected returns. Panel D reports the sum of the autocorrelation component and the cross-autocorrelation component. The results are based on all stocks listed on the Tokyo Stock Exchange (TSE) during 1975 to 1997. All numbers are presented in percentages. 
Table 6

Proportions of contrarian profits attributed to non-systematic components based on the Fama-French three-factor model

\begin{tabular}{|c|c|c|c|c|c|c|c|}
\hline \multirow{2}{*}{$\begin{array}{c}\text { Ranking horizon } \\
\text { in months (p) }\end{array}$} & \multicolumn{7}{|c|}{ Holding horizon in months (q) } \\
\hline & 1 & 3 & 6 & 9 & 12 & 24 & 36 \\
\hline \multicolumn{8}{|c|}{ Panel A: Abnormal return components $\left(\pi^{a}\right)$} \\
\hline \multirow[t]{2}{*}{1} & -0.002 & -0.001 & -0.000 & -0.000 & -0.000 & -0.000 & -0.000 \\
\hline & $(-3.22)$ & $(-2.31)$ & $(-1.78)$ & $(-1.85)$ & $(-1.65)$ & $(-0.93)$ & $(-0.74)$ \\
\hline \multirow[t]{2}{*}{3} & -0.006 & -0.002 & -0.001 & -0.001 & -0.000 & -0.000 & -0.000 \\
\hline & $(-7.18)$ & $(-4.25)$ & $(-3.71)$ & $(-3.13)$ & $(-2.70)$ & $(-1.30)$ & $(-0.93)$ \\
\hline \multirow[t]{2}{*}{6} & -0.012 & -0.004 & -0.002 & -0.001 & -0.001 & -0.000 & -0.000 \\
\hline & $(-12.76)$ & $(-7.91)$ & $(-6.52)$ & $(-5.15)$ & $(-3.08)$ & $(-1.45)$ & $(-0.95)$ \\
\hline \multirow[t]{2}{*}{9} & -0.018 & -0.006 & -0.003 & -0.002 & -0.001 & -0.001 & -0.000 \\
\hline & $(-19.10)$ & $(-9.75)$ & $(-8.19)$ & $(-4.40)$ & $(-2.79)$ & $(-1.38)$ & $(-0.90)$ \\
\hline \multirow[t]{2}{*}{12} & -0.024 & -0.008 & -0.004 & -0.002 & -0.002 & -0.001 & -0.001 \\
\hline & $(-23.15)$ & $(-11.71)$ & $(-6.39)$ & $(-3.70)$ & $(-2.51)$ & $(-1.26)$ & $(-0.85)$ \\
\hline \multirow[t]{2}{*}{24} & -0.045 & -0.015 & -0.007 & -0.005 & -0.004 & -0.002 & -0.001 \\
\hline & $(-19.34)$ & $(-7.38)$ & $(-4.27)$ & $(-2.82)$ & $(-2.07)$ & $(-1.03)$ & $(-0.71)$ \\
\hline \multirow[t]{2}{*}{36} & -0.068 & -0.022 & -0.011 & -0.007 & -0.005 & -0.003 & -0.002 \\
\hline & $(-20.51)$ & $(-7.79)$ & $(-4.20)$ & $(-2.68)$ & $(-1.97)$ & $(-1.00)$ & $(-0.72)$ \\
\hline \multicolumn{8}{|c|}{ Panel B: Firm-specific error components ( $\pi^{e}$ ) } \\
\hline \multirow[t]{2}{*}{1} & 0.072 & 0.033 & 0.019 & 0.012 & 0.010 & 0.008 & 0.007 \\
\hline & (111.39) & $(111.16)$ & $(110.32)$ & $(117.06)$ & $(114.80)$ & (117.99) & (121.04) \\
\hline \multirow[t]{2}{*}{3} & 0.097 & 0.030 & 0.055 & 0.022 & 0.018 & 0.021 & 0.018 \\
\hline & $(112.60)$ & $(117.14)$ & (119.38) & $(115.06)$ & $(114.21)$ & $(123.93)$ & $(124.43)$ \\
\hline \multirow[t]{2}{*}{6} & 0.115 & 0.063 & 0.036 & 0.028 & 0.032 & 0.039 & 0.036 \\
\hline & $(120.01)$ & $(125.81)$ & $(125.37)$ & (121.03) & $(112.96)$ & $(130.00)$ & $(122.91)$ \\
\hline \multirow[t]{2}{*}{9} & 0.120 & 0.073 & 0.044 & 0.047 & 0.055 & 0.063 & 0.058 \\
\hline & (126.54) & (121.13) & (126.81) & (113.96) & (113.95) & (130.12) & (120.36) \\
\hline \multirow[t]{2}{*}{12} & 0.131 & 0.085 & 0.071 & 0.077 & 0.083 & 0.090 & 0.084 \\
\hline & (127.46) & (128.09) & (120.87) & (116.40) & (115.46) & (127.11) & (120.47) \\
\hline \multirow[t]{2}{*}{24} & 0.293 & 0.246 & 0.212 & 0.208 & 0.207 & 0.202 & 0.189 \\
\hline & (124.72) & (121.26) & (123.28) & (122.06) & (120.56) & (118.40) & (116.48) \\
\hline \multirow[t]{2}{*}{36} & 0.410 & 0.347 & 0.311 & 0.311 & 0.316 & 0.313 & 0.294 \\
\hline & (123.84) & (120.28) & (117.49) & (113.66) & (113.23) & (115.91) & $(118.01)$ \\
\hline
\end{tabular}

This table reports the results of the proportions of the contrarian profits unexplained by the Fama-French three-factor model. Panel A presents the pricing error (or the abnormal return) components in the Fama-French three-factor model, while Panel B shows the firm-specific error components. The numbers in the table are the average monthly dollar value of the profits due to non-systematic components (multiplied by 100). The numbers in parentheses are percentages that are expressed with respect to the total profits. 


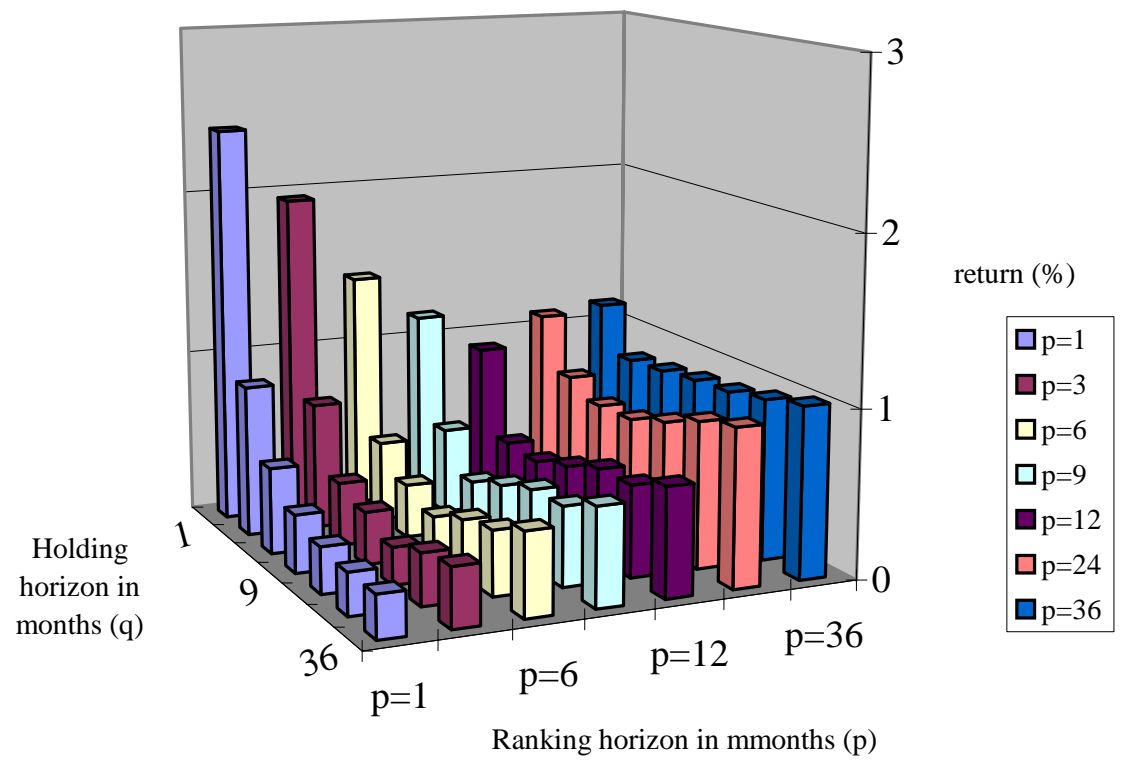

Figure 1: Average monthly contrarian profits 


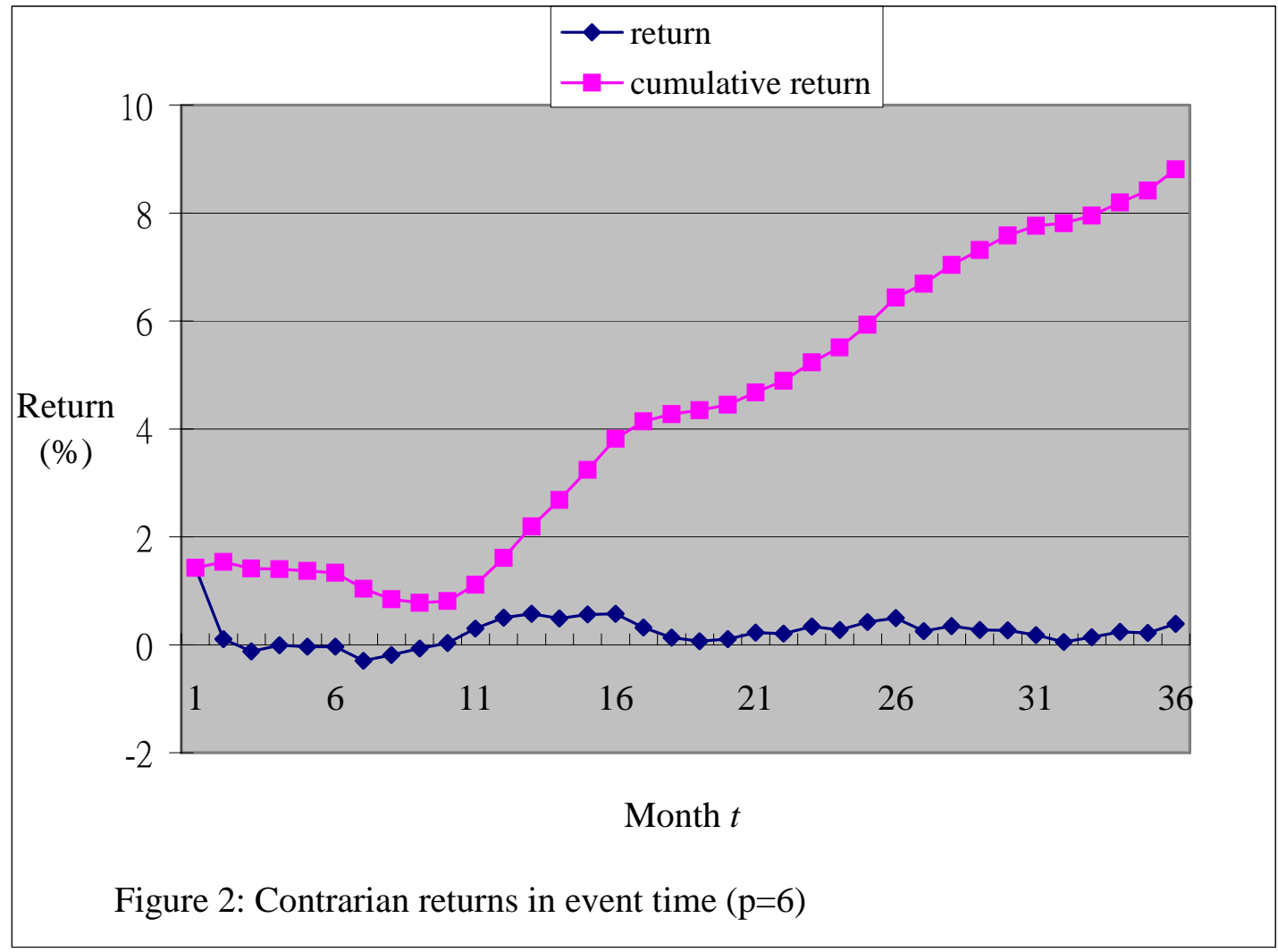




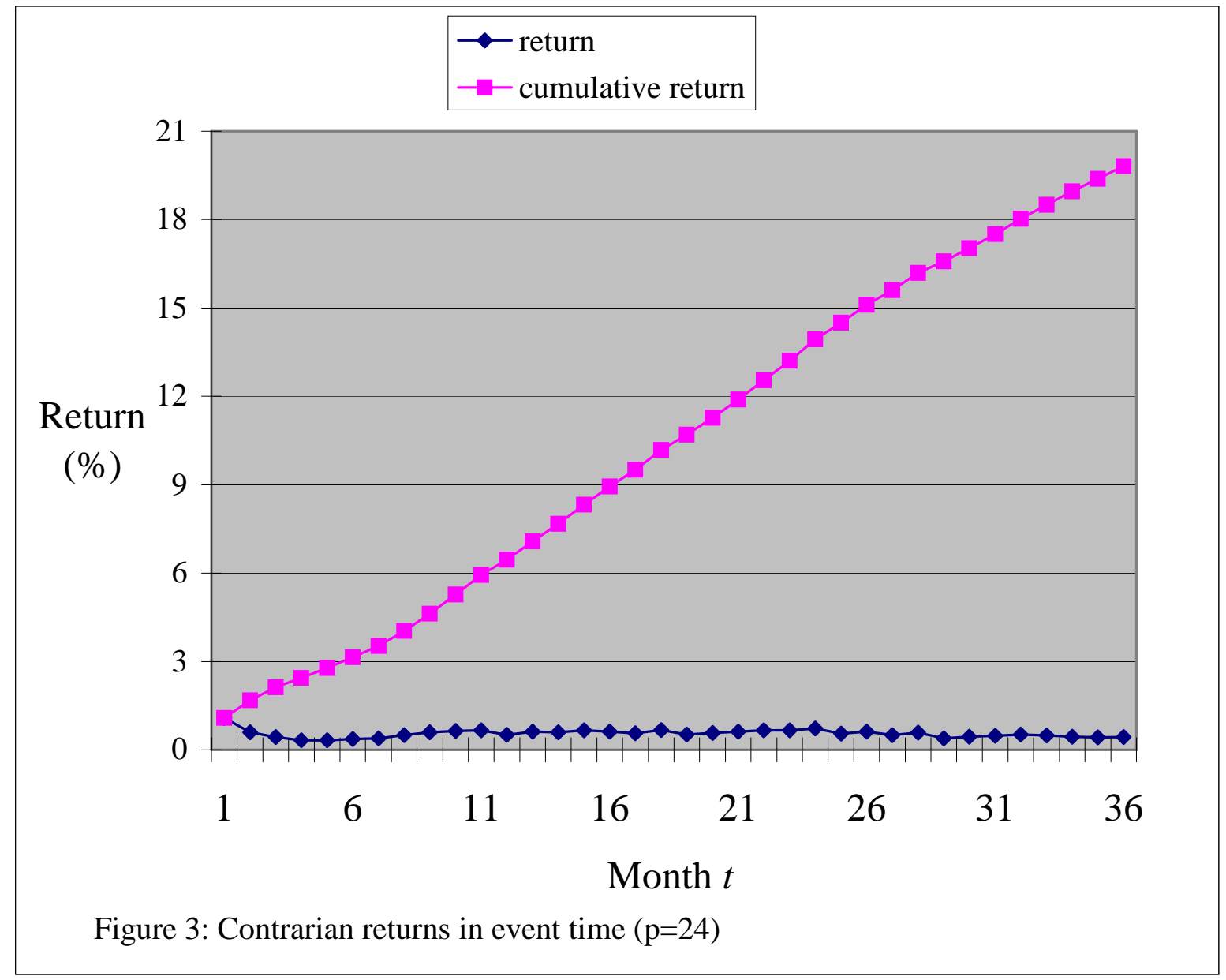

